
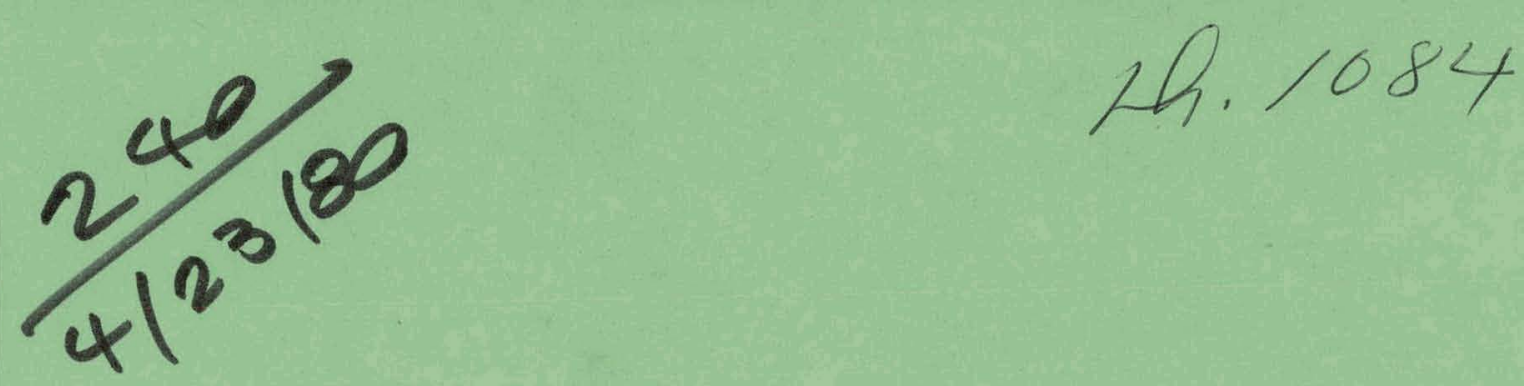

\title{
ENVIRONMENTAL CONTROL TECHNOLOGY FOR ATMOSPHERIC CARBON DIOXIDE
}

\section{FINAL REPORT}

\author{
Anthony S. Albanese \\ and Meyer Steinberg
}

September 1979

\section{PROCESS SCIENCES DIVISION}

DEPARTMENT OF ENERGY AND ENVIRONMENT

BROOKHAVEN NATIONAL LABORATORY ASSOCIATED UNIVERSITIES, INC.

UNDER CONTRACT NO. DE-ACO2-76CHOOO16 WITH THE

UNITED STATES DEPARTMENT OF ENERGY 


\section{DISCLAIMER}

This report was prepared as an account of work sponsored by an agency of the United States Government. Neither the United States Government nor any agency Thereof, nor any of their employees, makes any warranty, express or implied, or assumes any legal liability or responsibility for the accuracy, completeness, or usefulness of any information, apparatus, product, or process disclosed, or represents that its use would not infringe privately owned rights. Reference herein to any specific commercial product, process, or service by trade name, trademark, manufacturer, or otherwise does not necessarily constitute or imply its endorsement, recommendation, or favoring by the United States Government or any agency thereof. The views and opinions of authors expressed herein do not necessarily state or reflect those of the United States Government or any agency thereof. 


\section{DISCLAIMER}

Portions of this document may be illegible in electronic image products. Images are produced from the best available original document. 
BNL 51116

UC. 11

(Environmental Control Technology

and Earth Sciences - TID-4500)

\title{
ENVIRONMENTAL CONTROL TECHNOLOGY FOR ATMOSPHERIC CARBON DIOXIDE
}

\author{
FINAL REPORT
}

ANTHONY S. ALBANESE

and Meyer SteInberg

September 1979

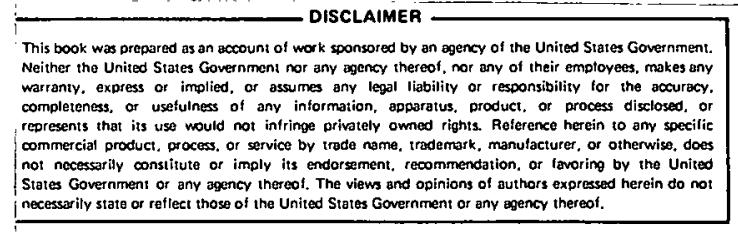

Work Performed For The

Division of Environmental Control Technology

United States Department of Energy

Washington, D.C. 20545

PROCESS SCIENCES DIVISION

DEPARTMENT OF ENERGY AND ENVIRONMENT

BROOKHAVEN NATIONAL LABORATORY

UPTON, NEW YORK 11.973 


\section{DISCLAIMER}

'l'his book was prepared as an account of work sponsored by an agency of the United States Government. Neither the United States Government nor any agency thereof, nor any of their employees, makes any warranty, express or implied, or assumes any legal liability or responsibility for the accuracy, completeness, or usefulness of any information, apparatus, product, or process disclosed, or represents that its use wnuld not infringe privately owned rights. Reference herein to any specific commercial producl, fmiress, ur service lay irarle uame, traclemark, manufacturer, or otherwise, docs not necessarily constitute or imply its endorsement, recommendation, or favoring by the United States Government or any agency thereof. The views and opinions of authors expressed herein do not necessarily state or reflect those of the United States Government or any agency thereof.

Printed in the United States of America Available from

National Technical Information Service

U.S. Department of Commerce

5285 Port Royal Road

Springfield, VA 22161

Price: Printed Copy ; Microfiche 
The Impact of fossil fuel use in the United States on worldwide $\mathrm{CO}_{2}$ emissions and the impact of increased coal utilization on $\mathrm{CO}_{2}$ emission rates are assessed. The aspects of $\mathrm{CO}_{2}$ control are discussed as well as the available $\mathrm{CO}_{2}$ control points $\left(\mathrm{CO}_{2}\right.$ removal sites).

The primary factor affecting the practicability of a $\mathrm{CO}_{2}$ control system is the energy required by the control system. Of the three potential $\mathrm{CO}_{2}$ control points, removal from the stacks of fossil fuel power plants appears to require the least amount of energy. Estimates of the energy required to capture and recover $\mathrm{CO}_{2}$ from coal-fired power plant stacks by various processes are presented.

Although capture and recovery of $\mathrm{CO}_{2}$ is an important consideration in the overall scheme of $\mathrm{CO}_{2}$ control, disposal or reuse of recovered $\mathrm{CO}_{2}$ may be the weakest link in the $\mathrm{CO}_{2}$ control chain. Of the several options considered, deep ocean storage appears to be the most promising.

Two control scenarios are evaluated, one based on the absorption of $\mathrm{CO}_{2}$ contained in power plant flue gas by seawater; the other, based on absorption of $\mathrm{CO}_{2}$ by MEA. Captured $\mathrm{CO}_{2}$ is injected into the deep ocean in both cases. Our analyses indicate that capture and disposal by seawater is not feasible, whereas capture and disposal using MEA is a possibility. However, the economic penalties of $\mathrm{CO}_{2}$ control are significant; for example, at a $\mathrm{CO}_{2}$ removal efficiency of $50 \%$, it is estimated that the power generation efficiency of a conventional coal fired power plant would be reduced from $34 \%$ to about $25 \%$. The cost of power generation would be expected to double. For $90 \% \mathrm{CO}_{2}$ removal, power 
generation efficiency is reduced to between 15 and $6 \%$ and the cost of power generation increases by a factor of from 4 to 7 .

The use of non-fossil energy sources, such as nuclear or solar energy, to control the $\mathrm{CO}_{2}$ emissions resulting from fossil energy usage is not considered in this study. 


\begin{tabular}{|c|c|}
\hline & Page \\
\hline ABSTRACT & iii \\
\hline INTRODUCTION & 1 \\
\hline IMPACT OF U.S. EMISSIONS & 3 \\
\hline IMPACT OF COAL UTILIZATION & 4 \\
\hline $\mathrm{CO}_{2}$ CONTROL OVERVIEW & 5 \\
\hline $\begin{array}{l}\mathrm{CO}_{2} \text { REMOVAL AND RECOVERY } \\
\text { Atmosphere and Oceans } \\
\text { F1ue Gas }\end{array}$ & $\begin{array}{l}7 \\
7 \\
9\end{array}$ \\
\hline $\begin{array}{l}\mathrm{CO}_{2} \text { DISPOSAL (STORAGE) } \\
\text { Injection in the Deep Ocean } \\
\text { Terrestrial Burial } \\
\text { Storage in Plants and Trees }\end{array}$ & $\begin{array}{r}9 \\
10 \\
11 \\
11\end{array}$ \\
\hline $\mathrm{CO}_{2}$ CONVERSION & 12 \\
\hline $\begin{array}{l}\text { REMOVAL AND DEEP OCEAN DISPOSAL OF } \\
\text { FLUE GAS } \mathrm{CO}_{2} \text { USING SEAWATER } \\
\text { Scenario Formulation and Description } \\
\text { Flue Gas Composition } \\
\mathrm{CO}_{2} \text { Solubility Data } \\
\text { Transfer Units } \\
\text { Tower Design } \\
\text { Packing Height } \\
\text { Energy Requirements } \\
\text { System Costs } \\
\text { Discussion }\end{array}$ & $\begin{array}{l}12 \\
12 \\
13 \\
13 \\
15 \\
16 \\
17 \\
17 \\
18 \\
19\end{array}$ \\
\hline $\begin{array}{l}\text { REMOVAL OF } \mathrm{CO}_{2} \text { FROM FLUE GAS USING MEA, } \\
\text { FOLLOWED BY DEEP OCEAN DISPOSAL } \\
\text { MEA Absorption/Stripping } \\
\text { Deep Ocean Disposal of Recovered } \mathrm{CO}_{2} \\
\text { a) Gaseous disposal } \\
\text { b) Liquid disposal } \\
\text { c) Solid disposal } \\
\text { Energy Requirements } \\
\text { Investment and Power Generation Costs } \\
\text { Discussion }\end{array}$ & $\begin{array}{l}20 \\
20 \\
21 \\
22 \\
22 \\
24 \\
25 \\
26 \\
27\end{array}$ \\
\hline CONCLUS IONS & 29 \\
\hline ACKNOWLEDGMENT & 31 \\
\hline REFERENCES & 31 \\
\hline TABLES & 33 \\
\hline F IGURES & 45 \\
\hline
\end{tabular}




\section{INTRODUCTION}

During the last one hundred years or so, the release of fossil carbon as $\mathrm{CO}_{2}$ has increased at an exponential rate as shown in $\mathrm{Fig} .1 .1$ As a result, the concentration of $\mathrm{CO}_{2}$ contained in the atmosphere has grown by about 12\%, increasing from about 295 ppm by volume in 1860 (pre-Industrial Revolution) to the current level of $331 \mathrm{ppm}$. Except for short periods during World Wars I and II and the Depression, the release rate of fossil carbon has increased at the rate of about $4.3 \%$ per year. ${ }^{2}$ At present, with no $\mathrm{CO}_{2}$ emission controls, about $5 \times 10^{9}$ metric tons of carbon per year as $\mathrm{CO}_{2}$ are emitted to the atmosphere by the burning of fossil fuels from worldwide sources. About $50 \%$ of this carbon can be accounted for by the increased $\mathrm{CO}_{2}$ concentration in the atmosphere. The remaining carbon is presumably absorbed by the oceans and by the land biomass; however, the actual quantities of $\mathrm{CO}_{2}$ absorbed by the land biomass and by the oceans are still undetermined. Deforestation considerations tend to complicate the issue even further.

If the use of fossil fuels continues to grow at $4.3 \%$ per year until the estimated supplies are exhausted, the use rate at the end of this period (about 100 years) would be almost 64 times the current use rate, and the total $\mathrm{CO}_{2}$ injected into the atmosphere during this period would be about 12 times the pre-industrial content of the atmosphere. Based on more reasonable assumptions, it is predicted that the concentration of atmospheric $\mathrm{CO}_{2}$ relative to the pre-industrial value could increase by a factor of from about 2 (low-use case) to about 5 (high-use case) during the next one hundred years. ${ }^{2}$ The low-use case corresponds to a fossil fuel growth rate of $2 \%$ per year until the year 2025 , followed by a 
symmetrical decrease as alternative and renewable energy sources become more available and the use of fossil fuel is discouraged. The high-use case corresponds to an initial annual growth rate of $4.3 \%$ with subsequent reductions in proportion to the ultimate fossil fuel supply that has been consumed. In both cases, about $50 \%$ of the emitted fossil carbon is assumed to be taken up by the oceans and 1and biomass.

of primary concern is the warming ("greenhouse effect") which may be produced by these increased $\mathrm{CO}_{2}$ concentrations due to the absorption by $\mathrm{CO}_{2}$ of a portion of the infrared radiation returning to space frum the earth. The amount of warming produced by a given $\mathrm{CO}_{2}$ concentration increase is estimated at $1^{\circ}$ to $5^{\circ} \mathrm{K}$ per doubling of the $\mathrm{CO}_{2}$ concentration. For the low-use case described above, this corresponds to a mean global temperature rise of from about $1^{\circ}$ to $5^{\circ} \mathrm{K}$ over the next one hundred years and from about $2^{\circ}$ to $10^{\circ} \mathrm{K}$ for the high-use case. A temperature rise of 10 or $2^{\circ} \mathrm{K}$ during this period may be acceptable; luwever, a risc of $10^{\circ} \mathrm{K}$. would probably cause catastrophic climatic and environmental effects. Increased concentrations of particulate matter in the global air mass might produce a cooling effect by backscatter of incoming solar radiation and thus counteract, to some degree, the warming produced by increasing $\mathrm{CO}_{2}$ levels. However, environmental emission regulations on particulates, as well as on other identified pollutants, have become more and more stringent during recent yoars and the trend is expected to continue. Furthermore, to deliberately attempt to counteract the effects of $\mathrm{CO}_{2}$ by allowing increased emissions of particulate pollutants does not appear to be a prudent strategy. Besides, it is not certain whether the net effect of man-made dust is one of cooling or warming of the atmosphere. 
Thus, since there is a chance that naturally occurring and/or anthropogenic opposing factors will not just counter the effects of increasing $\mathrm{CO}_{2}$ levels, it may be necessary to limit industrial $\mathrm{CO}_{2}$ emissions in the not too distant future. Up to the present, there has been practically no concern about the environmental effects of $\mathrm{CO}_{2}$; accordingly, there are no regulations applicable to $\mathrm{CO}_{2}$ emissions. Options for $\mathrm{CO}_{2}$ control have received little attention and al though preliminary evaluations indicate that control is theoretically possible, 1t may not be technically or economically practicable. It is thus important at this time to determine the technical feasibility and economic costs of $\mathrm{CO}_{2}$ control should the need arise for regulating the quantity of $\mathrm{CO}_{2}$ contained in the atmosphere.

\section{IMPACT OF U.S. EMISSIONS}

In order to determine the impact of fossil fuel use in the United States on overall (worldwide) $\mathrm{CO}_{2}$ emissions, we have superimposed several points on Figure 1, based on U.S. fuel use data for the years 1950, 1955, $1960,1965,1970,1973,3$ and 1976.1 The points were obtained by subtracting the estimated emissions of carbon (as $\mathrm{CO}_{2}$ ) by U.S. sources from the corresponding worldwide emissions for each of the above years, and thus indicate the quantities of carbon that would have been emitted if the U.S. had not burned any fossil fuels during these years. The reduction in carbon (and thus in $\mathrm{CO}_{2}$ ) by this hypothetical non=uec of fossil fuels in the U.S. ranges from $0.32 \mathrm{ppm}$ in 1950 to $0.64 \mathrm{ppm}$ in 1973 (and in 1976) as given in Table 1. However, during this period the percentage of the total yearly emissions contributed by the U.S. decreased from $43 \%$ in 1950 to $27 \%$ in 1976 . Furthermore, it is projected 
that the contribution to global $\mathrm{CO}_{2}$ production by the U.S. and Canada w111 decrease to about $8 \%$ by the year 2025. Developing nations will account for $36 \%$ of the $\mathrm{CO}_{2}$ production, the USSR and Eastern Europe $27 \%$, Asia 19\%, Western Europe $7 \%$, and Japan and Austral1a $3 \% .1$ Thus, it appears that a worldwide effort would be required to effectively control the level of atmospheric $\mathrm{CO}_{2}$.

\section{IMPACT OF COAL UTILIZATION}

Table 2 contains a source distribution of the carbun $\left(\mathrm{CO}_{2}\right)$ produced from major worldwide sources during the years 1970 through 1976.1 For the year 1976, using the heating values of $18,000 \mathrm{Btu} / \mathrm{lb}$ of contained carbon for coal, $22,400 \mathrm{Btu} / \mathrm{lb}$ carbon for fuel o11, and $31,500 \mathrm{Btu} / \mathrm{bb}$ carbon for natural gas, and assuming that all fossil energy was produced by the burning of solid coal, the carbon released to the atmosphere would have been roughly $6 \times 10^{9}$ metric tons or about 1.2 times the quantity actually emitted (energy differences required in mining versus drilling, preparation, transportation, etc. and in combustion efflclencies were not taken into account). If we had assumed that the natural gas and petroleum consumed in 1976 had been replaced by coal-dertved gaseous and liquid fuels, the quantity of carbon released to the atmosphere would have been even greater than $6 \times 10^{9}$ metric tons because of inefficlencies in the gasification and liquefaction processes. Thus, added reliance on coal for energy production could compound the atmospheric release rate of $\mathrm{CO}_{2}$, depending upon the extent to which coal displaces oil and natural gas and future energy use patterns. 
Table 3 shows the quantities of $\mathrm{CO}_{2}$ produced per unit energy released for various naturally occurring and synthetic fuels. In determining the $\mathrm{CO}_{2}$ generated by synthetic fuels such as $\mathrm{SNG}$, the $\mathrm{CO}_{2}$ generated in the production process is included. It is noted that natural gas produces about one third the amount of $\mathrm{CO}_{2}$ per unit energy released in comparison to synthetic natural gas derived from coal, and about half the $\mathrm{CO}_{2}$ from the direct burning of coal.

$\mathrm{CO}_{2}$ CONTROL OVERVIEW

Perhaps the most significant difference between the control of $\mathrm{CO}_{2}$ and that of other pollutants is that the amount of $\mathrm{CO}_{2}$ generated by the activities of mankind is so much greater--currently about $20 \times 10^{9}$ metric tons per year from the use of fossil fuels. Effective control would therefore require an extremely large-scale application of technology and the expenditure of large amounts of energy and capital. Methods for removing $\mathrm{CO}_{2}$ from gases and liquids are currently available ${ }^{4}$; however, reuse or storage/disposal alternatives are extremely limited. Pretreatment options are obviously nonexistent.

Although there are several key factors to consider in assessing the practicability of a prospective control methodology, the most important consideration is the energy required by the control system. As this energy increases, assuming that the energy required to drive the control system is furnished by fossil fuel, overall power plant efficiency decreases and the quantity of $\mathrm{CO}_{2}$ emitted to the atmosphere per $\mathrm{kWh}(\mathrm{e})$ generated increases. Therefore, in the extreme a point is reached where the only effect produced by the $\mathrm{CO}_{2}$ control system is a decrease in power plant efficiency with no net redurtion in $\mathrm{CO}_{2}$ emissions. 
Conventional coal-fired power plants operate at efficiencies of between 30 and $38 \%$. At an efficiency of $30 \%, 0.43 \mathrm{kWh}$ of electricity is produced per pound of $\mathrm{CO}_{2}$ generated; at $38 \%$ about $0.55 \mathrm{kWh}$. Table 4 . shows the effect of $\mathrm{CO}_{2}$ control system energy requirements and $\mathrm{CO}_{2}$ removal efficlency on overall power plant efficiency and on net $\mathrm{CO}_{2}$ emissions for an initial power plant efficiency of $38 \%$.

Three potential sontrol points ( $\mathrm{CO}_{2}$ removal sites) are available for regulating the concentration of $\mathrm{CO}_{2}$ in the armosphert: (1) the atmosphere 1tself, (2) the surface waters of the oceans, and (3) the stacks of fossil fuel power plants. The last site has the advantage of providing a source of relatively high $\mathrm{CO}_{2}$ concentration, while the first two provide more flexibility for site selection and simpler disposal or recovery and reuse logistics. A choice of control point limits the available choices of $\mathrm{CO}_{2}$ removal processes and will reflect on the size of operation, the number of required sites, energy requirements, the comparative economics, and the overall feasibllity of operation.

The $\mathrm{CO}_{2}$ concentration ranges of the three control points are listed in Table 5. Since the concentration of $\mathrm{CO}_{2}$ in flue gas is significantly greater than that in the atmosphere or the oceans, the energy required to remove $\mathrm{CO}_{2}$ from flue gas should be appreciably lower than for the other two control points. The minimum theoretical energies required to separate $\mathrm{CO}_{2}$ from each of the three sources are also listed in lable 9. Based on these theoretical values, it would take about three times more energy to separate $\mathrm{CO}_{2}$ from the atmosphere than from flue gas. 
Although removal or capture of $\mathrm{CO}_{2}$ from a particular source is an important consideration in devising a $\mathrm{CO}_{2}$ control system or scenario, $\mathrm{CO}_{2}$ disposal (storage) and reuse potentials are equally or perhaps more important, for unless a control scenario produces a net near-term decrease in the rate of buildup of atmospheric $\mathrm{CO}_{2}$ it will be of no value. This means that the captured $\mathrm{CO}_{2}$ must be stored or recycled until large-scale non-fossil energy sources become available.

A block diagram showing the relationship between the various aspects of $\mathrm{CO}_{2}$ control is presented in Figure 2 .

$$
\mathrm{CO}_{2} \text { REMOVAL AND RECOVERY }
$$

Atmosphere and Oceans

The present concentration of $\mathrm{CO}_{2}$ contained in the atmosphere is about $331 \mathrm{ppm}$ by volume. Therefore, in order to remove 1 mole of $\mathrm{CO}_{2}$ from the atmosphere a minimum of 3021 moles of air must be processed. This is equivalent to about one pound of $\mathrm{CO}_{2}$ per 2000 pounds of air. The equation for calculating the air horsepower of a fan can be simplified to 5

$$
\text { Air h.p. }=157 \times 10^{-6} \mathrm{Q \Delta P} \text {, }
$$

where $Q$ is the volume handled in $c$ fu and $\Delta P$ is the pressure drop across the fan in inches of water. For air at standard conditions, this equation may be converted to

$$
\text { Air h.P. }=34.9 \times 10^{-6} \mathrm{~W} \Delta \mathrm{P} \text {, }
$$

where $W$ equals the mass flow rate of air in pounds per hour. Assuming a fan efficiency of $75 \%$, the required shaft horsepower of the fan is

$$
\text { Shaft h.p. }=46.5 \times 10^{-6} \mathrm{~W} \Delta \mathrm{P} \text {. }
$$

Converting horsepower to kilowatts yields

$$
\begin{aligned}
\mathrm{kW} \text { fan }=34.7 \times 10^{-6} \mathrm{~W} \Delta \mathrm{P} & =34.7 \times 10^{-6}(\mathrm{~m} / \theta) \mathrm{P} . \\
& -7-
\end{aligned}
$$


Dividing by pounds of $\mathrm{CO}_{2}$ and substituting 2,000 pounds of air per pound of $\mathrm{CO}_{2}$ for $\mathrm{m}$ yields the following equation:

$$
\frac{\mathrm{kWh}(\mathrm{e})}{\mathrm{Ib} \mathrm{CO}_{2}}=0.0694 \Delta \mathrm{P}
$$

Assuming an overall power plant efficiency of $38 \%$ and a coal heating value of $18,000 \mathrm{Btu}$ per pound of contained carbon, the pounds of $\mathrm{CO}_{2}$ produced per kilowatt generated calculates to 1.83 . Setting $1 / 1.83$ $(0.5464)$ equal to $\mathrm{Eq} .(5)$, and solving for $\Delta \mathrm{P}$ yields $\Delta \mathrm{P}=7.9$ inches of water. Thus, if the pressure drop across a $\mathrm{CO}_{2}$ absorption or adeorption unit is equal to about 8 in. of water (assuming a 100\% removal efficiency and electricity generation by the combustion of coal), as much $\mathrm{CO}_{2}$ will be generated in supplying electricity to the air-handling fan as will be removed from the atmosphere by the $\mathrm{CO}_{2}$ removal system. For electricity generation by the combustion of natural gas instead of coal, $\triangle \mathrm{P}$ maximum calculates to $14 \mathrm{in.} \mathrm{of} \mathrm{water.} \mathrm{Since} \mathrm{a} \mathrm{maximum} \mathrm{allowable} \mathrm{pressure} \mathrm{drop}$ of from 8 to $14 \mathrm{in.}$ of water is a rather stringent constraint to impose on such equipment (actually the pressure drop would have to be much less than the calculated maximum allowable for the process to be of value), and since there are other system energy requirements to satisfy, e.g., sorbent pumping energy in absorption systems, it is unlikely that a practicable system can be designed for removing $\mathrm{CO}_{2}$ from the atmosphere unless non-fossil energy sources are considered. Note that Steinberg and Dang ${ }^{6}$ determined that the energy required to remove $\mathrm{CO}_{2}$ from the atmosphere by refrigeration techniques was greater than that required for removal by atmospheric absorption or adsorption processes. 
From the work of Steinberg and Dang and because of the low concentration of $\mathrm{CO}_{2}$ in seawater, it is also concluded that removal of $\mathrm{CO}_{2}$ from the oceans by a fossil fuel energy source is not a promising alternative. Flue Gas

The concentration of $\mathrm{CO}_{2}$ in fossil fuel power plant flue gas is about 500 times greater than its concentration in the atmosphere, therefore, $\mathrm{CO}_{2}$ removal should be greatly facilitated. Furthermore, commercial processes, 1.e., absorption/desorption processes, are currently available for removing $\mathrm{CO}_{2}$ from flue gas and other gaseous mixtures. For example, in the manufacture of liquid $\mathrm{CO}_{2}$ and dry ice, $\mathrm{CO}_{2}$ resulting from the burning of a carbonaceous material is absorbed from flue gas with sodiun carbonate, aqueous potassium carbonate, or amines. $\mathrm{CO}_{2}$ removal systems are also employed in the production of synthesis gases for ammonia and methanol, and in hydrogen gas production. Thus, removal of $\mathrm{CO}_{2}$ from flue gas appears to be much more promising than removal from the atmosphere or oceans.

Estimates of the energy requirements for removing $\mathrm{CO}_{2}$ from flue gas are given in Table 6. Values range from $0.15 \mathrm{kWh}(\mathrm{e}) / 1 \mathrm{~b} \mathrm{CO}_{2}$ for $50 \%$ absorption with monoethanolamine (MEA) to $0.8 \mathrm{kWh}(\mathrm{e}) / \mathrm{Ib} \mathrm{CO}_{2}$ for $90 \%$ absorption with seawater. The most effective solvent appears to be MEA; however, even the use of MEA will significantly reduce overall power plant efficiency.

$$
\mathrm{CO}_{2} \text { DISPOSAL (STORAGE) }
$$

Four ways of disposing of captured $\mathrm{CO}_{2}$ have been considered: injection in the deep ocean, (2) terrestrial burial (3) storage in plants and trees, and (4) extraterrestrial disposal. The last method is consldered Impractical because of the large quantities of $\mathrm{CO}_{2}$ involved. 
Injection in the Deep Ocean

In the two-box model, the world ocean is represented by two reservolrs, separated by a thermocline. One reservoir consists of surface layers to a depth of about 100 meters; the other, of deeper layers from the 100-meter depth to the ocean floor. Mixing is assumed to occur rapidly within each box or reservoir, but exchange between the two hnxes proceeds slowly. Thus, the deep ocean is a potential sink for $\mathrm{CO}_{2}$ since there is no direct exchange berween the atmosphere and deep ocean waters. Only the surface layers are in $\mathrm{CO}_{2}$ equilibrium with the atmosphere. The main discrepancy between the simple two-box model and the real ocean is that in some reglons (e.g., Arctic, Antarctic, and Gibraltar) convection currents extend from the ocean surface to the ocean bottom.

One proposal for disposing of collected $\mathrm{CO}_{2}$ is to inject it into the sea at the Stralt of Gibraltar.' Presumably, the current would carry it to the deeper ocean waters where it would remain for centurles. Another proposal is to inject. Ilquid $\mathrm{CO}_{2}$ into the deep sea at a density greater than that of deep sea water via a long pipe. ${ }^{24}$ The $\mathrm{CO}_{2}$ would sink to the bottom of the ocean forming a liqu1d $\mathrm{CO}_{2}$ lake within the ocean. $\mathrm{CO}_{2}$ could also be injected into the deep ocean as a gas, provided the injection depth is deep enough to permit dissolution of the $\mathrm{CO}_{2}$ before it rises to the upper layers.

The current release rate of fossil carbon to the atmosphere is about $5 \times 10^{15} \mathrm{~g} / \mathrm{yr}$, whereas the current carbon content of the deep ocean is estimated to be at $0.373 \times 10^{20} \mathrm{~g}$. Therefore, if all this fossil carbon was captured and deposited in the deep ocean, its carbon content over a 
one-year period would increase by only about $0.013 \%$. However, the effects of this injected carbon on the deep ocean ecosystem have not been assessed.

Terrestrial Burial

Storage in abandoned mine shafts or wells and fixation in natural clays are two options that were considered. The latter has been dismissed as impractical because of the large quantities of clays that would have to be handled, even if they were available and effective in fixing $\mathrm{CO}_{2}$. In the case of below ground storage the rate at which $\mathrm{CO}_{2}$ would re-enter the atmosphere is an important consideration as well as the available storage capacity of the below-ground cavities. A related disposal scheme is to use captured $\mathrm{CO}_{2}$ for enhanced oil recovery, in which case, the $\mathrm{CO}_{2}$ would be injected into depleted oil wells to effect additional oil recovery. Captured $\mathrm{CO}_{2}$ would thus have an economic value. However, the effectiveness of such a method in controlling atmospheric $\mathrm{CO}_{2}$ does not principally depend on economics but upor (1) the energy requirements of the $\mathrm{CO}_{2}$ removal and disposal system, (2) how much $\mathrm{CO}_{2}$ can be injected into depleted wells, and (3) the length of time the $\mathrm{CO}_{2}$ would remain underground. These factors have not been studied in enough detail to draw any firm conclusions. Storage in Plants and Trees

It has been suggested that in the event of a $\mathrm{CO}_{2}$ worldwide emergency, corrective measures to halt or reverse the growth of atmospheric $\mathrm{CO}_{2}$ could be instituted by planting fast-growing long-lived trees which are left unharvested and/or by growing short-lived plants 
which are converted to humus or allowed to accumulate in artificial peat bogs. However, this action would be limited by the availability of fertilizer. 8 Furthermore, additional $\mathrm{CO}_{2}$ would be generated by the reforestation activities and in supplying energy for increased fertilizer production, which would reduce the effectiveness of the method.

$$
\mathrm{CO}_{2} \text { CONVERSION }
$$

Although a number of commercial $\mathrm{CO}_{2}$ products can be made for the economy, e.g., dry lee, the quantity of these proninstis produced atud. consumed yearly is extremely small in comparison to the quantity of fossil $\mathrm{CO}_{2}$ emitted to the atmosphere. Therefore, atmospheric $\mathrm{CO}_{2}$ levels will not be significantly affected by the way in which these products are made.

A suggested method $6,9,10$ for reducing the buildup of $\mathrm{CO}_{2}$ in the atmosphere is to recover and convert $\mathrm{CO}_{2}$ to synthetic liquid and gaseous carbonaceous fuels using a non-fossil energy source such as nuclear or solar energy. The use of non-fossil energy to control the $\mathrm{CO}_{2}$ emissions resulting from fossil energy usage is not considered in this study. REMOVAL AND DEEP OCEAN DISPOSAL OF FLUE GAS $\mathrm{CO}_{2}$ USING SEAWATER Scenario Formulation and Description

In light of the previous considerations, control point 3 (power plant stacks) has been selected as the initial control point of interest. Accordingly, a scenario based on the absorption of $\mathrm{CO}_{2}$ generated by coal-fired power plants has been formulated. A block diagram of the system 1s presented in Figurc 3. Seawater. from the surface of the ocean is pumped to the top of a $\mathrm{CO}_{2}$ absorber (packed tower). The seawater flows downward through the packing by gravity, absorbing $\mathrm{CO}_{2}$ from the 
power plant flue gas which flows countercurrent to the seawater. The water exits at the bottom of the absorber and is pumped to the deep ocean while the treated flue gas is discharged to the atmosphere. The flue gas is fed to the absorber, subsequent to $\mathrm{SO}_{2}$ removal, by an auxiliary blower. Such a system is perhaps the simplest for one-step absorption and disposal of $\mathrm{CO}_{2}$. No $\mathrm{CO}_{2}$ desorption step is required and no additional handing of recovered $\mathrm{CO}_{2}$; the captured $\mathrm{CO}_{2}$ is discharged directly into a $\mathrm{CO}_{2}$ reservoir. Furthermore, seawater is readily available in large quantities at a zero purchase price. However, the scenario does impose constraints on power plant location.

In evaluating the subject scenario, it was assumed that the power plant under consideration has a capacity of $200 \mathrm{MW}(e)$ and an efficiency of about $34 \%$ (subsequent to $\mathrm{SO}_{2}$ removal), is located near the U.S. coastline at sea level, and that deep ocean waters are accessible at a distance of about 10 miles from the power plant site. Flue Gas Composition

A summary of the composition and conditions of the flue gas upon which this evaluation is based is presented in Table 7. Flue gas composition was calculated on the assumption that combustion is carried out with $20 \%$ excess air. It was also assumed that the gaseous feed to the $\mathrm{CO}_{2}$ absorber is saturated with water vapor at $120^{\circ} \mathrm{F}\left(48.9^{\circ} \mathrm{C}\right)$ and is free of sulfur dioxide. $\mathrm{CO}_{2}$ Solubility Data $\mathrm{CO}_{2}$ solubility data for pure water ${ }^{11}$ and for seawater at a salinity of $3.5 \% 12$ are summarlzed in Table 8 , for a temperature of $64.4^{\circ} \mathrm{F}\left(18^{\circ} \mathrm{C}\right)$. From these data, the equilibrium relationships between the partial 
pressure of $\mathrm{CO}_{2}$ in atmospheres as a function of its molar concentration in pure water and in seawater $(3.5 \%$ salinity) are $P=1390 \mathrm{x}$ and $\mathrm{P}=$ 1620x, respectively. Plots of $\mathrm{CO}_{2}$ partial pressure versus mole fraction for pure water and for seawater are presented in Figure 4 along with two absorber operating lines, one for a $\mathrm{CO}_{2}$ removal efficiency $(\pi)$ of 0.6 $(60 \%)$; the other, for a removal efficiency of 0.9 . The operating lines were determined by material balance and are given by 13

$$
L_{m}^{\prime}\left(x_{1}-X\right)=G_{m}^{\prime}\left(\frac{p 1}{p-p_{1}}-\frac{p}{p-p}\right) \text {. }
$$

where

$$
\begin{aligned}
& L_{m}^{\prime}=1 \text { iquor rate, } 1 \mathrm{~b} / \mathrm{mole} \text { solute-free solvent } /(\mathrm{hr})\left(\mathrm{ft}^{2} \text { tower }\right), \\
& G_{m}^{\prime}=\text { superficial molar mass velocity of inert gas, } \\
& 1 b-\mathrm{mole} /(\mathrm{hr})\left(\mathrm{ft} \mathrm{t}^{2}\right) \text {, } \\
& X \text { = solute concentration in liquid, lb-mole solute/lb-mole solvent, } \\
& x_{1}=\text { solute concentration in liquid leaving the tower, lb-mole solute/ } \\
& \text { lb-mole solvent, } \\
& \mathrm{P}=\text { total pressure on system, atm, } \\
& \mathrm{p}=\text { partial pressure of solute in gas stream, atm, } \\
& p_{1}=\text { partial pressure of solute in gas entering the tower, atm. }
\end{aligned}
$$

The effects of pressure drop across the column and of condensation of water vapor from the flue gas during passage through the absorber are not taken into account In the above equation. For the system inder consideration, the $1 \mathrm{~b}$-mole solute/1b-mole solvent ( $\mathrm{X}$ ) is about equal to the mole fraction of solute in the liquid $\operatorname{stream}(x)$. 


\section{Transfer Units}

When the resistance to mass transfer is principally in the liquid phase, as in the case of phystcal absorption of a slightly soluble gas (e.g., $\mathrm{CO}_{2}$ ), it is customary to base tower calculations on liquid-phase transfer units. Following this convention, the applicable equation for calculating the number of overall liquid-phase transfer units is

$$
N_{O L}=\int_{x_{2}}^{x_{1}} \frac{d x}{x^{*-x}}
$$

where

$$
\begin{aligned}
\mathrm{N}_{\mathrm{OL}}= & \text { number of overall liquid-phase transfer units, } \\
\mathrm{x}_{1}= & \text { mole fraction of solute in liquid stream at concentrated } \\
& \text { end of countercurrent apparatus, } \\
\mathrm{x}_{2}= & \text { mole fraction of solute in liquid stream at dilute end of } \\
& \text { countercurrent apparatus, } \\
x^{*}= & \text { mole fraction of solute in liquid at equilibrium with bulk } \\
& \text { of gas, } \\
\mathrm{x}= & \text { mole fraction of solute in liquid stream. }
\end{aligned}
$$

For straight operating and equilibrium lines, the equation can be written

$$
\mathrm{N}_{\mathrm{OL}}=\frac{\mathrm{x}_{1}-\mathrm{x}_{2}}{\left(\mathrm{x}^{*}-\mathrm{x}\right) \mathrm{LM}}
$$

where

$$
\left(x^{*-x}\right)_{\operatorname{LM}}=\frac{\left(x^{*-x}\right)_{2}-\left(x^{*-x}\right)_{1}}{\ln \left[\left(x^{*-x}\right)_{2} /\left(x^{*-x}\right)_{1}\right]}
$$


For $\eta=0.60, x_{2}=0.2 \times 10^{-6}$ (fresh seawater), and $x_{1}=70 \times 10^{-6}$ (spent seawater), $\mathrm{N}_{\mathrm{OL}}$ calculates to 3.3. For $n=0.90, \mathrm{x}_{2}=0.2 \times 10^{-6}$, and $\mathrm{x}_{1}=80 \times 10^{-6}, \mathrm{~N}_{\text {OL }}$ is 16.3

\section{Tower Design}

Following the conventional technique for tower design, $(L / G)\left(\rho_{G} / \rho_{L}\right)^{\frac{1}{2}}$ was calculated and $G$ determined from the Generalized Pressure Drop Correlation for Packed Towers [Figure 5] (Norton Chemical Process Products Division)], relating $G^{2} F \psi p 0.2 / \rho_{G} \rho_{T}, g_{C}$ to $(L / G)\left(\rho_{G} / \rho_{T}\right)^{\frac{1}{2}}$, where

$$
\begin{aligned}
& L=1 \text { iquid rate, } 1 \mathrm{~b} / \mathrm{sec}-\mathrm{ft}^{2}, \\
& G=\text { gas rate, } \mathrm{lb} / \mathrm{sec}-\mathrm{ft}^{2}, \\
& \rho_{L}=1 \text { iquid density, } 1 \mathrm{~b} / \mathrm{ft}^{3}, \\
& \rho_{G}=\text { gas density, } 1 \mathrm{~b} / \mathrm{ft}^{3}, \\
& F=\text { packing factor, } \\
& \mu=\text { viscosity of } 1 \text { iquid, centipoise, } \\
& \psi=\text { ratio, density of water/density of liquid, } \\
& g_{c}=\text { gravitational constant }=32.2 \text {. }
\end{aligned}
$$

Two-inch Raschig rings and a pressure drop of 0.5 inches of water per foot packing were assumed. Note that it was necessary to extrapolate the curves of the subject pressure drop correlation because of the high L/G ratios required by the $\mathrm{CO}_{2}$ absorber. Operating, a tower at high $(L / G)\left(\rho_{G} / \rho_{L}\right)^{\frac{1}{2}}$ values could result in tower instabilify.

For the $n=0.6$ case, the value of $G$ was determined to 1 ie between 0.018 and $0.021 \mathrm{~b} / \mathrm{sec}-\mathrm{ft}^{2}$. Based on the flow of flue gas iudicated in Table 7 and the above values of $\mathrm{G}$, between 84 and 90 towers of $20-\mathrm{ft}$ 
diameter would be required to achieve the $60 \%$ removal efficiency. For $\eta=0.9$, between 100 and 107 towers of $20-\mathrm{ft}$ diameter are required. Packing Height

With m (slope of equilibrium line), L, G, and tower diameter established, the height of an overall liquid-phase transfer unit $\left(\mathrm{H}_{\mathrm{OL}}\right)$ was estimated for each of the cases under consideration from data appearing in ref. $11, \mathrm{p} .221$. For $\eta=0.60, \mathrm{H}_{\mathrm{OL}}$ was estimated to be $7 \mathrm{ft}$ and for $\eta=0.90$, at $8 \mathrm{ft}$. For the former case the required height of packing, given by $\mathrm{h}=\mathrm{N}_{\mathrm{OL}} \mathrm{H}_{\mathrm{OL}}$, is 23 feet and for the latter $130 \mathrm{ft}$. The corresponding pressure drops across the absorbers (with some contingency) are 15 and $70 \mathrm{in.}$ of water, respectively. A summary of the two cases appears in Table 9. Note that it was necessary to calculate $h$ before energy requirements could be assessed.

\section{Energy Requirements}

A flow sheet of the subject $\mathrm{CO}_{2}$ control system is shown in Figure 6; pumping distances and pipe sizes are also included in the diagram. The energy requirements of both the 60 and $90 \%$ cases are sumarized in Table 10. The major energy requirement, as would be expected, is due to the high seawater pumping load. A relatively minor quantity of energy is required to pump the flue gas through the absorbers. For each of the $\mathrm{CO}_{2}$ removal efficiencies considered, more $\mathrm{CO}_{2}$ would be produced in supplying electricity to the control system (assuming coal-derived power and electrically driven equipment) than would be extracted from the power plant flue gas. For the $60 \%$ efficiency case, about $0.6 \mathrm{kWh}(\mathrm{e}) / \mathrm{lb} \mathrm{CO}_{2}$ captured is required and for the $90 \%$ case, about $0.8 \mathrm{kWh}(\mathrm{e}) / \mathrm{lb} \mathrm{CO}_{2}$. 
At an overall power plant efficiency of $34 \%$ and a coal heating value of $18,000 \mathrm{Btu}$ per pound of contained carbon, only $0.5 \mathrm{kWh}$ of electricity is produced per pound of $\mathrm{CO}_{2}$ generated.

It should be.mentioned that the high horsepower and thus energy requirements of the seawater pumps are due to the large quantities of seawater (abouc $3 \times 10^{6} \mathrm{gpm}$ ) that must be supplied to and exhausted from the $\mathrm{CO}_{2}$ absorption towers (because of the low solub1lity of $\mathrm{CO}_{2} \mathrm{i}_{4}$ seawater); friction loss (for the selected pipe sizes) and staclc head requirements are not excessive (about 100 psi overal1). Furthermore, static head is dictated by absorber height and not by the depth to which the spent seawater must be pumped because the head against which the spent seawater is pumped is balanced by the static head gain of the spenc seawater in flowing from sea level to the deep ocean. However, the deeper the injection point the greater the friction loss (for a given pipe size and flow rate) because a greater length of pipe is required. System Costs

Estimates of the equipment requirements, fixed capital investments, and operating costs of the 60 and $90 \%$ removal systems are summarized in Table 11. The total fixed investment for the $60 \%$ sysletil is estimated at about $\$ 123,300,000$, and for the $90 \%$ system at $\$ 226,800,000$. Yearly operating costs (utilities only) are $\$ 35,500,000$ and $\$ 72,2000,000$, respectively, assuming an electricity cost of $30 \mathrm{mill} / \mathrm{s} / \mathrm{kWh}$ and 8,000 hours of plant operation. For comparison, the fixed capital investment and yearly operating costs (utilities and raw materials only) of a lime slurry $\mathrm{SO}_{2}$ scrubbing system for a $200-\mathrm{MW}($ e) plant are roughly $\$ 20,000,000$ and $\$ 1,700,000$, respectively, assuming $3.3 \%$ sulfur coal (dry basis), an $80 \% \mathrm{SO}_{2}$ removal efficiency, and on-site disposal of spent slurry. 
$30 \mathrm{mills} / \mathrm{kWh}$ corresponds to the approximate cost of electricity purchased from an external source, that is, from a power plant without $\mathrm{CO}_{2}$ control. For a power plant that uses its own electrical output to drive its $\mathrm{CO}_{2}$ control system (self-contained plant), the revenue requirements and thus cost of generating electricity will depend upon the net electrical output of the plant. Therefore, as net output approaches zero (because of excessive demands by the $\mathrm{CO}_{2}$ control system), revenue requirements will approach infinity, which is the case for seawater absorption/disposal of $\mathrm{CO}_{2}$ from power plant flue gas.

Discussion

Although the subject scenario offers the following advantages as compared, for example, to a scenario based on absorption by a chemical solvent - (1) simple plant design (no heat exchangers, desorption equipment and reboilers), (2) no heat load, (3) inexpensive, readily available solvent, (4) no solvent vapors introduced into the gas stream, and (5) direct disposal of captured $\mathrm{CO}_{2}$ - it is not a promising alternative because of excessive energy and equipment requirements. Furthermore, site location is restricted and absorber stability may be a problem.

For the two $\mathrm{CO}_{2}$ collection efficiencies considered, the $\mathrm{CO}_{2}$ produced in supplying energy to the control system would be greater than the $\mathrm{CO}_{2}$ removed from the flue gas. The energy requirements of the control system can be reduced somewhat by increasing the sizes of the seawater transfer lines and/or by lowering $\mathrm{CO}_{2}$ collection efficiency. However, equipment requirements would remain substantial. The system may be more attractive if used in combination with an ocean thermal energy conversion (OTEC) system; but, OTEC systems are highly speculative at the present time. 
REMOVAL OF $\mathrm{CO}_{2}$ FROM FLUE GAS USING MEA, FOLLOWED BY DEEP OCEAN DIS POSAL MEA Absorption/Stripping

Of the several processes evaluated for removing $\mathrm{CO}_{2}$ from stack gases (Table 6), monoethanolamine (MEA) absorption/stripping requires the least amount of energy per unit of $\mathrm{CO}_{2}$ recovered. MEA absorbs $\mathrm{CO}_{2}$ rapidly and efficiently at low partial pressures and is therefore well suited for removing $\mathrm{CO}_{2}$ frum power plant flue gac. Impurities such as $\mathrm{COS}, \mathrm{CS}_{2}$, $\mathrm{HCN}$, and $\mathrm{SO}_{2}$ react nonregenerably with $\mathrm{MEA}$ yu $3 \mathrm{O}_{2}$ iulist be removed from the flue gas prior to treatment with $\mathrm{SO}_{2}$. Flue gas does not normally contain $\mathrm{COS}, \mathrm{CS}_{2}$, or $\mathrm{HCN}$.

A flow sheet of the MEA process for $\mathrm{CO}_{2}$ absorption recovery from power plant flue gas is shown in Figure $7.19,20$ Flue gas at $120^{\circ} \mathrm{F}$ and 14.7 psia (water saturated) from bulk $\mathrm{SO}_{2}$ removal is fed to the suction of a blower which compresses the flue gas to about 16 psia and feeds it to the MEA absorber. As the tlue gas passes chrough the dusuiliei, $\mathrm{CO}_{2}$ is removed by reaction with lean MEA solution, flowing countercurrent to the flue gas, in accordance with the following reaction:

$$
\mathrm{HO}\left(\mathrm{CH}_{2}\right)_{2} \mathrm{NH}_{2}+\mathrm{H}_{2} \mathrm{O}+\mathrm{CO}_{2} \rightleftarrows \mathrm{HO}\left(\mathrm{CH}_{2}\right)_{2} \mathrm{NH}_{3} \mathrm{HCO}_{3} \text {. }
$$

The reaction takes place to the right (forward direction) at temperatures between about $100^{\circ}$ and $175^{\circ} \mathrm{F}$.

Spent MEA solution is pumped frum lie luttuin of the aboorbcr through a filter, for removal of solid impurities, to the top of the regenerator. Before entering the regenerator, the cold spent MEA solution is heated by heat exchange with the hot regeneraced (lean) sulution from the bottom of the regenerator. Carbon dioxide is stripped from the MEA as the solution flows downward through the regenerator. A steam-heated reboiler 
supplies the necessary heat for regeneration. The bottom of the regenerator is maintained at about $250^{\circ} \mathrm{F}$. Elevated temperature combined with steam stripping favors the reverse of the absorption reaction.

The stripped carbon dioxide exits the regenerator at the top and flows to a condenser for removal of water vapor. Most of the condensed water is returned to the generator as reflux; a portion of the remainder is pumped to the top of the absorber to reduce MEA losses. Excess water is pumped to disposal.

Regenerated MEA solution from the bottom of the stripping tower is first cooled by heat exchange with spent MEA solution flowing to the stripper, and then by water. The cooled lean solution is then fed to the top of the absorber tower.

A reclaimer for recovering $M E A$ which has reacted with residual flue gas $\mathrm{SO}_{2}$ is shown at the bottom of the regenerator. A slipstream of MEA is withdrawn from the regenerator reboiler and cooled by heat exchange with the reclaimed solution returning to the reboiler. Sodium carbonate is added to the stream to liberate MEA. The slipstream is then cooled and filtered to remove precipitated sodium sulfate and sulfite and other degradation products. Purified MEA solution is returned to the reboiler. The reclaiming system is speculative at the present time and further development work is required before a final design can be prepared. 20 Deep Ocean Disposal of Recovered $\mathrm{CO}_{2}$

Three methods of disposing of the recovered gaseous $\mathrm{CO}_{2}$. from the $\mathbb{M} A$ absorption/stripping process were considered: (a) gaseous disposal via a deep ocean pipeline, (b) liquid disposal via a deep ocean pipeline, and (c) deep ocean solid disposal. 
(a) Gaseous Disposal. In gaseous disposal, $\mathrm{CO}_{2}$ recovered by the MEA process is compressed and fed to the deep ocean via a pipeline. A 500meter injection depth was assumed even though ocean surface layers usually extend to a depth of only about 100 meters. The additional 400 meters was provided to allow for dissolution of the injected gas in the deep ocean. Any injected $\mathrm{CO}_{2}$ which reaches the well-mixed surface layers will eventually equilibrate with the atmosphere and thus reduce the p.fectiveness of disposal. Ocean depths of 500 meters are accessible at distances of about 100 miles from the shoreline of the northeast United States (approximate width of the continental shelt); therefore, a pipeline of about 100 miles in length was assumed (no allowance was made for inland distance).

For $90 \%$ recovery of the $\mathrm{CO}_{2}$ generated by a $200-\mathrm{MW}(\mathrm{e})$ coal-fired power plant, an 18-in. line was selected; for $50 \%$ recovery, a 14-in. Iine was selected. Most of the energy required by the $\mathrm{CO}_{2}$ compressur is expended in overcoming the seawater static head between the $\mathrm{CO}_{2}$ injection point and the surface of the ocean. A compressor discharge pressure (third stage) of about 800 psia is required.

A block diagram of the overall absorption/recovery disposal system is shown in Figures 8 and 9.

(b) Liquid Disposal. In order to produce liquid $\mathrm{CO}_{2}$ from the gaseous $\mathrm{CO}_{2}$ product of the MEA systcm, the baseous $\mathrm{CO}_{2}$ muat be compressed, cooled, and dried. This is done in a three-stage compression system equipped with coolers, water knockout drums, and a dryer. The gas is compressed to 920 psia in the third stage, passed through a cooler, and liquefied in a condenser at about $27^{\circ} \mathrm{C}^{22}$ (the critical pressure and 
temperature of $\mathrm{CO}_{2}$ are 1073 psia and $31^{\circ} \mathrm{C}$ ). For deep ocean disposal, the liquefied $\mathrm{CO}_{2}$ would then be piped to an appropriate location in the deep ocean.

In order to store $\mathrm{CO}_{2}$ as a liquid pool in the deep ocean it must be injected to a depth where the density of $\mathrm{CO}_{2}$, at the pressure corresponding to the seawater static head and the prevailing seawater temperature, is greater than the density of the seawater at the injection point. The specific gravity of $\mathrm{CO}_{2}$ is approximately equal to 1 at pressures between 150 and 300 atmospheres and temperatures between $3^{\circ}$ and $15^{\circ} \mathrm{C}$. For the subject evaluation, an injection depth of 3000 meters was selected which corresponds to a pressure of about 300 atmospheres; the temperature of the ocean at this depth is about $3^{\circ} \mathrm{C}$. The specific gravity of $\mathrm{CO}_{2}$ (liquid) at these conditions is 1.05 . At a salinity of $3.5 \%$, a temperature of $3^{\circ} \mathrm{C}$, and a pressure of 300 atmospheres, the specific gravity of seawater is about 1.04 .

Ocean depths of 3000 meters are accessible at distances of about 200 miles from the shoreline of the northeast United States and thus a pipeline of about 200 miles in length is required (no allowance is made for Inland distance since the required offshore distance is quite variable with respect to the U.S. coastline). For $90 \%$ recovery of the $\mathrm{CO}_{2}$ generated by a $200-\mathrm{MW}(\mathrm{e})$ plant, a $12-\mathrm{in}$. line was selected; for $50 \%$ recovery, a 10-in. 1ine. For these line sizes, the liquid $\mathrm{CO}_{2}$ will flow to the deep ocean under the influence of the $\mathrm{CO}_{2}$ liquefaction pressure. Pumps are not required. In the subject evaluation it was assumed that the liquid would be cooled from about $27^{\circ} \mathrm{C}$ to the temperature of the deep ocean injection point during its journey to the deep ocean. If this is not the case, additional cooling of the liquid $\mathrm{CO}_{2}$ will be required. 
A block diagram of the overall absorption/recovery disposal system is shown in Figures 8 and 9.

(c) Solid Disposal. In the production of commercial solid $\mathrm{CO}_{2}$, the liquid $\mathrm{CO}_{2}$ produced by compression and cooling, as described under (b) above, 1s expanded through a nozzle, forming "snow," and fed to a press. The vapors given off during expansion are used to precool the liquid carbon dioxide prior to expansion. The gas 1 s then recimpressed and rellquofied. The "snow" is compressed into 220 pound blocks and then quartered by band saws. The 55-pound blocks are wrapped in Kraft paper and either stored or shipped in insulated cars. 22 The density of the blocks is about $100 \mathrm{Ib} / \mathrm{ft}^{3}$. The temperature of saturated $\mathrm{CO}_{2}$ ice at 1 atmosphere pressure is $-78.5^{\circ} \mathrm{C}$.

Since the density of the $\mathrm{CO}_{2}$ blocks is much greater than that of seawater, they should readily sink to the ocean bottom when dropped into the surface waters of the ocean. The settling velocity of a iU-in. cube of solid $\mathrm{CO}_{2}$ in seawater is roughly estimated at $5 \mathrm{ft} / \mathrm{secc}$. For a disposal depth of 500 meters (the depth selected for gaseous $\mathrm{CO}_{2}$ disposal) it would take about 5.4 minutes for a block to reach bottom; for a disposal depth of 3000 meters (che deplh selected for liquid $\mathrm{CO}_{2}$ disposal) it would take about 32 minutes. Based on the phase diagram for $\mathrm{CO}_{2}$ and assuming the blocks are heated by the seawater to prevallituy ocean temperatures, the final state of the blocks for both the 500- and 3000-meter disposal depths is liquid. The liquid formed for the 3000meter disposal depth will have a density greater than that of seawater and therefore should remain at the bottom of the ocean. For the 500meter depth, the liquid will be less dense then seawater and would 
therefore tend to rise. Upon rising, some of the liquid $\mathrm{CO}_{2}$ may dissolve in the seawater and some may flash into vapor which in turn will rise and dissolve. Depending upon the relative rates of heat and mass transfer and the rate of ascent of the $\mathrm{CO}_{2}$ liquid droplets and gaseous bubbles, some $\mathrm{CO}_{2}$ may reach the surface layers of the ocean. $\mathrm{CO}_{2}$ reaching these layers may eventually end up in the atmosphere. Losses may also occur as the blocks descend to the ocean bottom as a result of gas and liquid formation and dissolution. Without experimental data or a detailed analysis of the physics of deep ocean disposal of solid $\mathrm{CO}_{2}$, it is not possible to confidently predict the fate of the solid $\mathrm{CO}_{2}$ blocks or accurately determine the extent of losses.

The energy required to transport the solid $\mathrm{CO}_{2}$ blocks a distance of 100 miles offshore ( 500 -meter disposal depth) by barge is estimated at $0.005 \mathrm{kWh}(\mathrm{e}) / \mathrm{lb} \mathrm{CO}_{2}$ and for 200 miles (3000 meter depth) at 0.010 $k W h(e) / 1 b \mathrm{CO}_{2}$. The energy to produce solid $\mathrm{CO}_{2}$ blocks from gaseous $\mathrm{CO}_{2}$ is about $0.17 \mathrm{kWh}(\mathrm{e}) / \mathrm{lb} \mathrm{CO}$. Therefore, barging distance does not have a significant effect on the overall energy requirements of the system, assuming no $\mathrm{CO}_{2}$ losses during transport; however, disposal costs for the 200-mile distance would be almost twice that of the 100-mile distance.

A block diagram of the overall absorption/recovery disposal system is shown in Figures 8 and 9.

Energy Requirements

Total system energy requirements for $\mathrm{CO}_{2}$ recovery efficiencies of 50 and $90 \%$ and for gaseous, liquid, and solid disposal are summarized in Figures 8 and 9, respectively. At 50\% efficiency, gaseous or liquid disposal require the equivalent of about $0.20 \mathrm{kWh}(\mathrm{e}) / 1 \mathrm{~b} \mathrm{CO}_{2}$ recovered and 
at $90 \%$ efficiency about $0.32 \mathrm{kWh}(\mathrm{e}) / 1 \mathrm{~b} \mathrm{CO}_{2}$. For solid disposal at $50 \%$ recovery, assuning no sublimation losses during handling and transportation, about $0.33 \mathrm{kWh}(e) / 1 \mathrm{~b} \mathrm{CO} 2$ are required, whereas about 0.45 $\mathrm{kWh}(\mathrm{e}) / 1 \mathrm{~b} \quad \mathrm{CO}_{2}$ are needed at $90 \%$ recovery. Assuming a power plant efficiency of $34 \%$ after sulfur dioxide removal, $0.49 \mathrm{kilowatt-hours} \mathrm{of} \mathrm{electricity} \mathrm{is} \mathrm{produced} \mathrm{per} \mathrm{pound} \mathrm{of} \mathrm{CO}_{2}$ generated. With no $\mathrm{CU}_{2}$ removal, 2.04 pounds of $\mathrm{CO}_{2}$ are diseharged to the atmnsphere per net kilowatt-hour of electricity produced. At $30 \%$ recovery and gaseous or liquid disposal, overall power plant efficiency would be reduced to $27 \%$ and for $90 \%$ recovery to $14 \%$. The corresponding pounds of $\mathrm{CO}_{2}$ discharged to the atmosphere per net $\mathrm{kWh}(\mathrm{e})$ generated are 1.3 and 0.5 , respectively. For 50 and $90 \%$ recoveries and solld disposal, power plant efficiency would be reduced to 23 and $6 \%$, respectively. The corresponding pounds of $\mathrm{CO}_{2}$ discharged per net $\mathrm{kWh}(\mathrm{e})$ produced are 1.5 and 1.1 .

Investment and Power Generation Costs

Rough estimates of the required fixed capital investments for 50 and $9 n \% \mathrm{CO}_{2}$ recovery using MEA and for gaseous, liquid, and solid disposal are presented in l'ables 12 and 13. On Llie basis of thege eatimates and those of the capital and operating costs of a 200-MW(e) coal-tired power plant with flue gas desulfurization (FG'), electriciey generallull cusls have been calculated. These are presented in Table 14 along with an estimate of the cost of generation without $\mathrm{CO}_{2}$ control.

Revenue requirements in $\mathrm{mills} / \mathrm{kWh}$ were calculated on the basis of net electricity output assuming an initial plant capacity of $200 \mathrm{MW}(\mathrm{e})$ (after $\mathrm{SO}_{2}$ removal) and assuming that the electricity required to drive 
the $\mathrm{CO}_{2}$ control system is supplied internally by the subject power plant. Thus, the net output of the power plant ( $e_{\text {net }}$ ) is equal to gross output $\left[e_{\text {gross }}=200 \mathrm{MW}(\mathrm{e})\right]$ minus the electricity consumed by the control system (e $e_{\text {control }}$ ). A schematic of the overall system is presented in Figure 10. For a $\mathrm{CO}_{2}$ removal efficiency of $50 \%$, the costs of generating electricity for gaseous, liquid, and solid disposal are approximately equal. The net power generated and yearly operating costs for gaseous and solid disposal are about the same and, therefore, so are power generation costs. Solid disposal requires more energy but less capital. For $50 \%$ removal of $\mathrm{CO}_{2}$, these two factors balance one another and the cost of power generation for solid disposal turns out to be about the same as for gaseous and liquid disposal.

For $90 \% \mathrm{CO}_{2}$ removal, in comparison to $50 \%$, the cost of power generation roughly doubles for both gaseous and liquid disposal, whereas it increases by a factor of about 4 for solid disposal. This marked increase in generation costs for solid disposal is due to excessive control system energy requirements at the $90 \% \mathrm{CO}_{2}$ removal efficiency.

If the above analysis had been based on a net power plant output of $200 \mathrm{MW}(\mathrm{e})$ rather than a gross output of $200 \mathrm{MW}(\mathrm{e})$ the costs of power generation, particularly at the higher $\mathrm{CO}_{2}$ removal efficiencles, might have been somewhat lower because of economies of scale. Discussion

If we accept the previous results and evaluation, removal and recovery of flue gas $\mathrm{CO}_{2}$ using $\mathrm{MEA}$ is technically and energetically feasible; however, economic penalties are significant. Disposal also appears to be feasible provided the effects of injected $\mathrm{CO}_{2}$ on the deep ocean ecosystem are not prohibitive. 
MEA absorption/stripping in combination with either gaseous or 1iquid disposal requires appreciably less energy than an MEA-solid disposal combination. On the other hand, the capital investments required by the former combinations far exceed those of the latter, offsetting, to some degree, the economic benefits of the lower energy requirements. For gaseous or Ifquid disposal, the major portion of the capital investment is due to pipeline costs, which are probably understated in the cost estimates.

A posslble way to reduce the capital investment for a liquid disposal system is to barge 1 iquid $\mathrm{CO}_{2}$ to the required offshore distance (about 200 miles) and then inject the liquid into the deep ocean via a pipe extending from the ocean surface to the injection point. With this arrangement the required length of injection piping would be substantially reduced (from about 330,000 to about 3000 meters) as well as the required pipe size. Unfortunately, $\mathrm{CO}_{2}$ cannot be shipped as a liquid at atmospheric pressure as can LNG, therefore, high pressure barges or tankers, or numerous high pressure cylinders, would be required for transport. Gaseous $\mathrm{CO}_{2}$ could also be shipped under pressure and then in jected into the deep ocean.

For direct gaseous or Liquid deep ocean injection (via pipeline), essentially no losses of recovered $\mathrm{CO}_{2}$ would be incurred during transport. For solid disposal by barging, losses during handling and transportation could be significant. For 10-in. cube blocks of about 55 pounds each, shipping losses (based on transport by truck) could be as high as 8 pounds during the first 24 hours in summer. 23 To reduce 
handling losses and improve handling logistics for inland power plants, it may be better to pump the flue gas to the dock site and remove/recover and solidify at that point.

\section{CONCLUS IONS}

(1) The contribution by the United States to worldwide $\mathrm{CO}_{2}$ emissions has been decreasing during the last 25 years and it is projected that it will decrease even further during the next 50 years. Therefore, a worldwide effort will be required to control the buildup of atmospheric $\mathrm{CO}_{2}$.

(2) Increased utilization of coal for producing heat, electric power, and/or synthetic gaseous and liquid fuels will increase the rate of $\mathrm{CO}_{2}$ emissions. The magnitude of this increase may or may not be significant depending upon the extent to which coal displaces oil and natural gas, and future energy use patterns.

(3) Direct capture of $\mathrm{CO}_{2}$ from the atmosphere or capture from the surface waters of the oceans do not appear to be feasible if a fossil energy source is used to drive the $\mathrm{CO}_{2}$ control system.

(4) For 60 to $90 \%$ absorption of the $\mathrm{CO}_{2}$ contained in the flue gas of a coal-fired power plant using ccowater and deep ocean disposal, more $\mathrm{CO}_{2}$ would be generated in supplying energy to the control system than would be recovered from the flue gas.

(5) Removal and recovery of $\mathrm{CO}_{2}$ from the stacks of fossil fuel plants by commercially available processes is feasible, e.g., by absorption/stripping with MEA. However, large quantities of energy are required which will substantially reduce the efficiency of power generation and thus increase the cost of producing electricity. 
(6) Disposal of captured and recovered $\mathrm{CO}_{2}$ will be a problem. of the disposal/reuse options considered, deep ocean disposal appears to be a possibility. However, the costs of disposal are substantial. The effects of injected $\mathrm{CO}_{2}$ on the ocean ecosystem have not been assessed.

(7) Of the processes considered, absorption by MEA is the least energy intensive. For a $50 \% \mathrm{CO}_{2}$ removal efficiency, the equivalent of $0.15 \mathrm{kWh}(\mathrm{e}) / \mathrm{lb}$ captured $\mathrm{CO}_{2}$ is required; and for $90 \%$ removal, 0.27 $\mathrm{kWh}(\mathrm{e}) / \mathrm{Ib} \mathrm{CO}_{2}$. Gaseous or liquid disposal of the captured $\mathrm{CO}_{2}$ requires an additional $0.05 \mathrm{kWh}(\mathrm{e}) / 1 \mathrm{~b} \mathrm{CO}_{2}$, whereas solid disposal requires about $0.18 \mathrm{kWh}(\mathrm{e}) / 1 \mathrm{~b} \mathrm{CO} 2$ (discounting transportation and handling losses). The required capital investments for gaseous and liquid pipeline disposal are substantially greater than for solid disposal. Low energy consumption and high capital investment have offsetting effects on the cost of power generation.

(8) For effective control of atmospheric $\mathrm{CO}_{2}$ by removal from flue gases, it would be advantageous and perhaps necessary to centralize the use of fossil fuels, such as in an all electric cconomy, since it. would be almost impossible to remove, recover, and dispose of $\mathrm{CO}_{2}$ from the numerous small sources, i.e., from the flues of home heating units, process plants, and automob1le exlausts. In che U.S. Emtay, about 30\% of the total $\mathrm{CO}_{2}$ released to the atmosphere from the use of fossil fuels comes from large stationary sources (electric power plants).

For direct removal of $\mathrm{CO}_{2}$ from the atmosphere or from the surface layers of the ocean, centralized use of fossil fuels is not required. However, removal of $\mathrm{CO}_{2}$ directly from the atmosphere or from the oceans does not appear to be feasible unless the energy required to drive the $\mathrm{CO}_{2}$ control system is supplied by a non-fossil energy source. 


\section{ACKNOWLEDGMENT}

The authors wish to thank Dr.' Fred Witmer of the Division of

Environmental Control Technology of DOE for his helpful suggestions in the preparation of this work.

\section{REFERENCES}

1. R.M. Rotty, Global $\mathrm{CO}_{2}$ production from fossil fuels and cement, $\mathrm{AD}$ 1950-AD 2000, Proc. Mtg. at Univ. Hawaii on Fate and Fossil Fuel $\mathrm{CO}_{2}$ in the Ocean, Sponsored by Office of Naval Research Jan. 1976, Plenum Press, pp. 167-181, Oct. 1977.

2. C.F. Baes Jr., H.E. Goeller, J.S. Olson, and R.M. Rotty, Carbon dioxide and climate: The uncontrolled experiment, Am. Sci. 65, 310 (1977).

3. Statistical Abstract of the United States, U.S. Department of Commerce, 1975.

4. A. Albanese and M. Steinberg, Environmental Control Technology for Atmospheric Carbon Dioxide, BNL 50877, (Apr. 1978).

5. Chemical Engineers Handbook, R.H Perry and C.H. Chilton, Editors, 5th Ed., McGraw Hil1, 1973.

6. M. Steinberg and Vi-Duong Dang, Use of Controlled Thermonuclear Reactor Fusion Power for the Production of Synthetic Methanol Fuel from Air and Water, BNL 20016R, Apr. 1975.

7. C. Marchetti, on geoengineering and the $\mathrm{CO}_{2}$ problem, Climatic Charge 1,59 (1977).

8. F.J. Dyson, Can we control the carbon dioxide in the atmosphere, Fnergy 2, 287=291 (1977).

9. M. Steinberg, Nuclear Power for the Production of Synthetic Fuels and Feedstocks, BNL 21330, Apr. 1976.

10. M. Steinberg, Synthetic Carbonaceous Fuels and Feedstocks from Oxides of Carbon and Nuclear Power, BNL 22785, Mar. 1977.

11. Gas Purification, F.C. Reisenfeld and A.L. Kohl, 2nd Ed., Gulf Publishing Co., 1974 .

12. Chemical Oceanography, Vol. 2, J.P. Riley and G. Skirrow, Editors, 2nd Ed., Academic Press, 1975. 
13. Absorption and Extraction, T.K. Sherwood and R.L. Pigford, Editors, 2nd Ed., McGraw Hil1, 1952.

14. T.B. Reed, Efficiencies of Methanol Production from Gas, Coal, Waste or Wood, Lincoln Laboratory, MIT.

15. R. Detman, Factored Estimates for Western Coal Commercial Concepts, C.F. Braun \& Co., Interim Report, FE-2240-5, Oct. 1976.

16. R. Detman, Factored Estimates for Eastern Coal Comercial Concepto, C.F. Braun \& Co., Interim Report, FE-2240-31, Sept. 1978.

17. A.S. Albanese and M. Steinberg, Environmental Control Technology for the Flash Hydropyrolysis of Coal, Progress Report No. 3, BNL 50983, Feb. 1979.

18. P.J. Rogoshewski, Standards of Practice Manual for the Solvent Refined Coal Liquefaction Process, Hittman Assoclates, EPA-600/7-78-091, June 1978.

19. A.W. Pappano et a1., Avallability and Economics of $\mathrm{CO}_{2}$ for Enhanced $0 i 1$ Recovery in Appalachia, Dept of ChE, West Virginia University, TID-22787, Aug. 1976.

20. W.M. Rump et al., The Supply of Carbon Dioxide for Enhanced 011 Recovery, Pullman Kellog, Final Report, FE-2515-10, Sept. 1977.

21. R.M. Guthrie, Process Plane Est1mating Evaluation and Control, Craftsman Book Company of America, 1974.

22. Industrial Chemicals, W.L. Faith, D.B. Keyes, and R.L. Clark, Edllurs, 4th Ed.; John Wiley Snns, Inc. 1975.

23. E.L. Quinn and C.L. Jones, Carbon D1oxide, Reinhold Publishing Company, 1936.

24. W.D. Nordhaus, Can We Control Carbon Dioxide? IIASA-Working Paper WP-75-63, June 1975. 
Table 1

U.S. Contribution to Atmospheric $\mathrm{CO}_{2}$ Emissions Compared to All other Worldwide Sources 1,3

\begin{tabular}{|c|c|c|c|c|}
\hline Year & $\begin{array}{l}\begin{array}{l}\text { Incremental atm } \\
\text { concentratic }\end{array} \\
\text { Worldwide }\end{array}$ & $\begin{array}{l}\text { spheric } \mathrm{CO}_{2} \\
\text { In ppm } \\
\text { U.S. }\end{array}$ & $\begin{array}{c}\text { \% U.S. } \\
\text { contribution }\end{array}$ & $\%$ Others \\
\hline $\begin{array}{l}1950 \\
1955 \\
1960 \\
1965 \\
1970 \\
1973 \\
1976 \\
2025 \text { Est. }\end{array}$ & $\begin{array}{l}0.74 \\
0.92 \\
1.18 \\
1.47 \\
2.00 \\
2.27 \\
2.38\end{array}$ & $\begin{array}{l}0.32 \\
0.36 \\
0.39 \\
0.46 \\
0.58 \\
0.64 \\
0.64\end{array}$ & $\begin{array}{r}43 \\
39 \\
33 \\
31 \\
29 \\
28 \\
27 \\
8\end{array}$ & $\begin{array}{l}57 \\
61 \\
67 \\
69 \\
71 \\
72 \\
73 \\
92(1)\end{array}$ \\
\hline
\end{tabular}

(1) Developing nations estimated to account for $36 \%$ of total worldwide emissions.

\begin{tabular}{|c|c|c|c|c|c|c|c|c|}
\hline & $\mathrm{Al}$ & $\begin{array}{l}\text { Worlo } \\
\text { entrie }\end{array}$ & $\begin{array}{l}\text { de } \mathrm{CO}_{2} \\
\text { in } 10^{6}\end{array}$ & $\begin{array}{l}\text { Cable } 2 \\
\text { Emissio } \\
\text { metric }\end{array}$ & $\begin{array}{l}\text { by So } \\
\text { ns car }\end{array}$ & $\begin{array}{l}\text { ce } \\
\text { n as } c\end{array}$ & & \\
\hline Source & 1970 & 1971 & 1972 & 1973 & 1974 & 1975 & 1976 & $\begin{array}{c}1976 \\
\text { Distribution }\end{array}$ \\
\hline $\begin{array}{l}\text { Coal } \\
\text { Lignite } \\
\text { Crude petroleum \& }\end{array}$ & $\begin{array}{r}1497 \\
237\end{array}$ & $\begin{array}{r}1479 \\
239\end{array}$ & $\begin{array}{r}1499 \\
243\end{array}$ & $\begin{array}{r}1527 \\
246\end{array}$ & $\begin{array}{r}1550 \\
246\end{array}$ & $\begin{array}{r}1626 \\
249\end{array}$ & $\begin{array}{r}1676 \\
260\end{array}$ & $\begin{array}{r}33.2 \\
5.1\end{array}$ \\
\hline $\begin{array}{l}\text { N.G. liquids } \\
\text { Natural gas } \\
\text { Natural gas flared } \\
\text { Cement }\end{array}$ & $\begin{array}{r}1803 \\
545 \\
90 \\
82\end{array}$ & $\begin{array}{r}1907 \\
583 \\
94 \\
88\end{array}$ & $\begin{array}{r}2011 \\
614 \\
100 \\
93\end{array}$ & $\begin{array}{r}2203 \\
646 \\
110 \\
95\end{array}$ & $\begin{array}{r}2213 \\
659 \\
113 \\
95\end{array}$ & $\begin{array}{r}2107 \\
665 \\
105 \\
100\end{array}$ & $\begin{array}{r}2224 \\
675 \\
113 \\
99\end{array}$ & $\begin{array}{r}44.1 \\
13.4 \\
2.2 \\
2.0\end{array}$ \\
\hline $\begin{array}{l}\text { Total carbon } \\
\text { as } \mathrm{CO}_{2} \\
\text { Incremental atm } \\
\mathrm{CO}_{2} \text { conc. ( } \mathrm{ppm} \text { ) } \\
\text { U.S. emissions } \\
\text { contribution }\end{array}$ & 2.00 & 2.07 & 4560 & 4827 & $2.29^{\circ}$ & $\begin{array}{l}4852 \\
2.28\end{array}$ & $\begin{array}{l}5047 \\
2.38\end{array}$ & \\
\hline
\end{tabular}


Table 3

$\mathrm{CO}_{2}$ Generction for Various Fuels

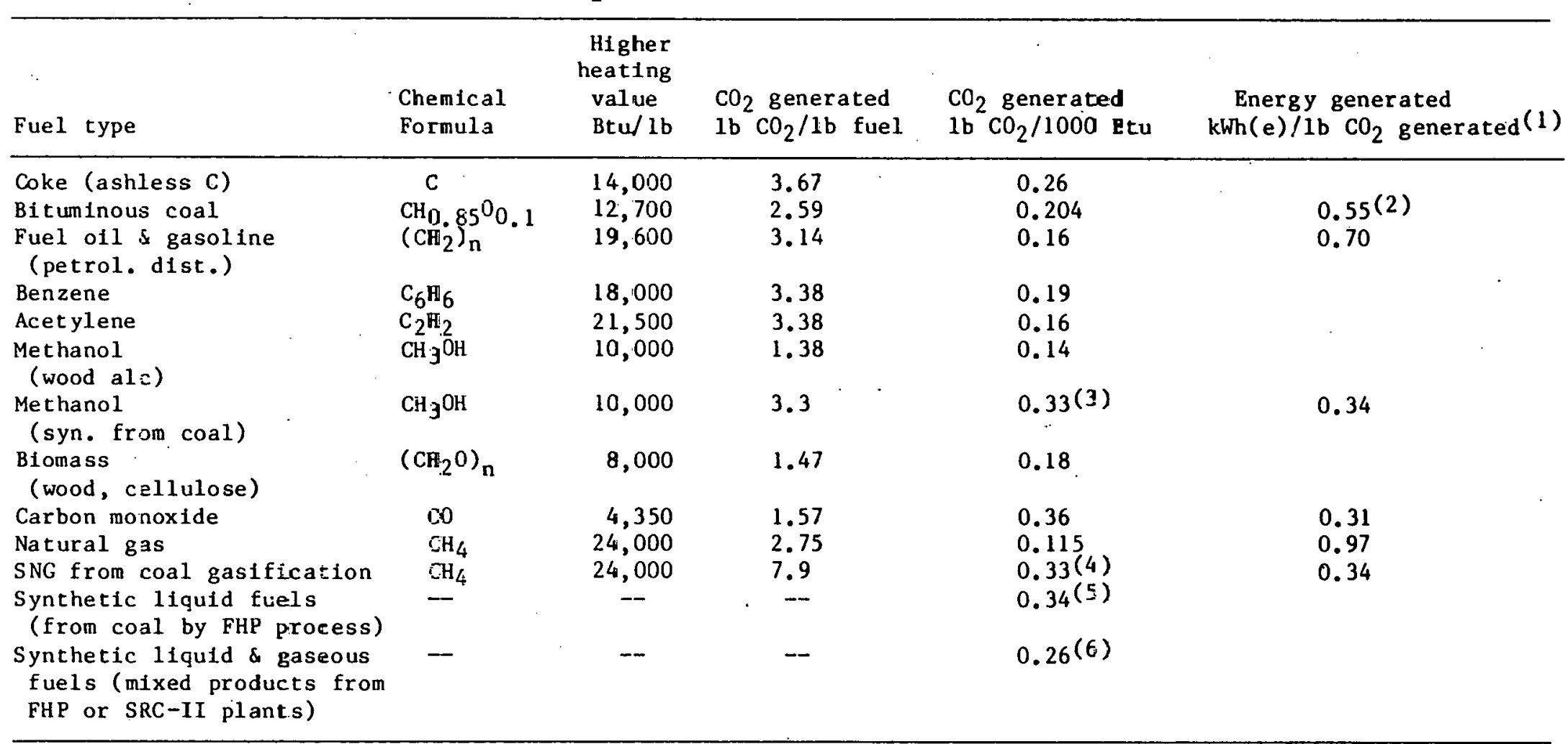

(1) Assuming a power p-ant effictency of $38 \%$.

(2) For a power plant with FGC, assuming power plant efficiency is reduced from $38 \%$ to $35 \%$, the $\mathrm{kWh}(\mathrm{e}) / \mathrm{lb} \mathrm{CO}_{2}$ generated is reduced to $0.5 \mathrm{~J}$.

(3) Estimated from zef. 14.

(4) Estimated from ref. 15 and 16.

(5) Estimated from zef. 17.

(6) Estimated from ref. 17 and 18. 
Table 4

Effect of $\mathrm{CO}_{2}$ Control System Energy

Requirements on Power Plant Efficiency

\begin{tabular}{|c|c|c|c|}
\hline $\begin{array}{l}\text { Energy required by } \\
\mathrm{CO}_{2} \text { control system } \\
\mathrm{kWh}(\mathrm{e}) / \mathrm{lb} \mathrm{CO}_{2}\end{array}$ & $\begin{array}{c}\mathrm{CO}_{2} \text { removal } \\
\text { efficiency, } \\
\%\end{array}$ & $\begin{array}{l}\text { Net power plant } \\
\text { efficiency } \\
\%\end{array}$ & $\begin{array}{l}\text { Ibs } \mathrm{CO}_{2} \text { discharged } \\
\text { to atmosphere per } \\
\text { net } \mathrm{kWh}(\mathrm{e}) \text { generated }\end{array}$ \\
\hline 0 & 100 & 38.0 & 0 \\
\hline 0.1 & $\begin{array}{r}100 \\
75 \\
50 \\
25 \\
0\end{array}$ & $\begin{array}{l}31.0 \\
32.8 \\
34.5 \\
36.3 \\
38.0\end{array}$ & $\begin{array}{l}0 \\
0.53 \\
1.01 \\
1.44 \\
1.83\end{array}$ \\
\hline 0.2 & $\begin{array}{r}100 \\
75 \\
50 \\
25 \\
0\end{array}$ & $\begin{array}{l}24.1 \\
27.6 \\
31.0 \\
34.5 \\
38.0\end{array}$ & $\begin{array}{l}0 \\
0.63 \\
1.12 \\
1.51 \\
1.83\end{array}$ \\
\hline 0.3 & $\begin{array}{r}100 \\
75 \\
50 \\
25 \\
0\end{array}$ & $\begin{array}{l}17.1 \\
22.4 \\
27.6 \\
32.8 \\
38.0\end{array}$ & $\begin{array}{l}0 \\
0.78 \\
1.26 \\
1.59 \\
1.83\end{array}$ \\
\hline 0.4 & $\begin{array}{r}100 \\
75 \\
50 \\
25 \\
0\end{array}$ & $\begin{array}{l}10.2 \\
17.1 \\
24.1 \\
31.0 \\
38.0\end{array}$ & $\begin{array}{l}0 \\
1.01 \\
1.44 \\
1.68 \\
1.83\end{array}$ \\
\hline. & $\begin{array}{r}100 \\
75 \\
50 \\
25 \\
0\end{array}$ & $\begin{array}{r}3.2 \\
11.9 \\
20.6 \\
29.3 \\
38.0\end{array}$ & $\begin{array}{l}0 \\
1.46 \\
1.69 \\
1.78 \\
1.83\end{array}$ \\
\hline 0.55 & $\begin{array}{r}100 \\
\cdot \quad 75 \\
50 \\
25 \\
0\end{array}$ & $\begin{array}{c}0 \\
9.5 \\
19.0 \\
28.5 \\
38.0\end{array}$ & $\begin{array}{l}0 \\
1.83 \\
1.83 \\
1.83 \\
1.83\end{array}$ \\
\hline
\end{tabular}


Table 5

$\mathrm{CO}_{2}$ Concentrations at Control Points and Minimum $\mathrm{CO}_{2}$ Separation Energies

\begin{tabular}{lccc}
\hline Control point & \multicolumn{2}{c}{$\mathrm{CO}_{2}$ concentration } & $\frac{\text { Min separation energy (1) }}{\mathrm{kWh} / 1 \mathrm{~b} \mathrm{CO}_{2}}$ \\
\hline (1) Atmosphere & $331 \times 10^{-4}$ & $502 \times 10^{-4}$ & 0.0570 \\
(2) Ocean & - & $100 \times 10^{-4}(2)$ & 0.0570 \\
(3) Fossil fueled power & $7-20$ & $11-28$ & $0.0259-0.0179$ \\
\hline
\end{tabular}

(1) Minimum energy based on free energy of mixing: $\Delta F=R T \sum n_{1} \ln \left(P_{i} / P_{i}{ }^{\circ}\right)$, where $P_{i}{ }^{\circ}$ and $P_{1}$ are the initlal and final partial pressures of the $I^{\text {th }}$ specles, respectively. $R$ is the gas coustant, $T$ is temperature in degrees absolute, and $n_{i}$ is the number of moles of the $i^{\text {th }}$ species.

(2) $\quad \mathrm{CO}_{2}$ (total carbon dioxide content) $=\mathrm{C}_{\mathrm{H}_{2} \mathrm{CO}_{3}}+\mathrm{C}_{\mathrm{CO}_{2}(\mathrm{aq})}+\mathrm{C}_{\mathrm{HCO}_{3}}(\mathrm{~T})+\mathrm{C}_{\mathrm{CO}_{3}}(\mathrm{~T})$.

Table 6

Energy Required To Remove and Recover $\mathrm{CO}_{2}$ (Gaseous) From Flue Gas

\begin{tabular}{|c|c|c|}
\hline Process & $\begin{array}{l}\mathrm{CO}_{2} \text { removal } \\
\text { offirienry \% }\end{array}$ & $\begin{array}{l}\mathrm{kWh}(\mathrm{e}) \mathrm{sb} / \mathrm{CO}_{2}(1,2,3) \\
\text { recover } \mathrm{d}\end{array}$ \\
\hline 1. Amine (MEA) absorption/Strlpping & $\begin{array}{l}50 \\
90\end{array}$ & $\begin{array}{l}0.15 \\
0.27\end{array}$ \\
\hline 2. Potassium carbonate absorption/stripping & 90 & 0.32 \\
\hline 3. Molernlar sieves & 90 & 0.10 \\
\hline 4. Refrigeration & 90 & 0.40 \\
\hline 5. Seawater absorption (4) & $\begin{array}{l}60 \\
90\end{array}$ & $\begin{array}{l}0.60 \\
0.80\end{array}$ \\
\hline
\end{tabular}

(1) Energy required to recover $\mathrm{CO}_{2}$ (as a gas) frum flue gas of eonl-fircd power plant subsequent to $\mathrm{SO}_{2}$ removal. Inlet conditions to $\mathrm{CO}_{2}$ removal process are $120^{\circ} \mathrm{F}$ and $14.7 \mathrm{psta}$, assuming flue gas is saturated with water vapor and free of $\mathrm{SO}_{2}$. Reheat of flue gas accounted for by $\mathrm{SO}_{2}$ system.

(2) All energy requirements have been converted to the equivalent amount of electrical energy.

(3) To 1iquefy the recovered $\mathrm{CO}_{2}$ gas, an additional $0.05 \mathrm{kWh}(\mathrm{e}) / 1 \mathrm{~b} \mathrm{CO}_{2}$ is required; to solidify the $\mathrm{CO}_{2}$ gas, about $0.17 \mathrm{kWh}(\mathrm{e}) / 1 \mathrm{~b} \mathrm{CO} 2$ is required.

(4) Including deep ocean disposal of captured $\mathrm{CO}_{2}$. 
Table 7

Summary of Flue Gas from 200 MWe Coal

Fired Power Plant at 20\% Excess Air

\begin{tabular}{crrrr}
\hline Component & M.W. & \multicolumn{1}{c}{$1 \mathrm{~b} / \mathrm{hr}$} & \multicolumn{1}{c}{$1 \mathrm{~b}$-mol/hr } & $\begin{array}{c}\text { Mole } \\
\text { percent }\end{array}$ \\
\hline $\mathrm{O}_{2}$ & 32 & 70,873 & $2,214.8$ & 3.155 \\
$\mathrm{~N}_{2}$ & 28 & $1,401,550$ & $50,055.4$ & 71.295 \\
$\mathrm{H}_{2} \mathrm{O}$ & 18 & 153,552 & $8,530.7$ & 12.150 \\
$\mathrm{CO}_{2}$ & 44 & $\frac{413,967}{2,408.3}$ & $\underline{13.400}$ \\
& & $2,039,942$ & $70,209.2$ & 100.0 \\
\hline
\end{tabular}

MW(avg): 29.06

$P($ psia): 14.7

$\mathrm{T}\left({ }^{\circ} \mathrm{F}\right): 120^{\circ}$

Basls : Flue gas composition at discharge of $\mathrm{SO}_{2}$ scrubbers flue gas assumed to be $\mathrm{SO}_{2}$ free and saturated with water vapor at $120^{\circ} \mathrm{F}$. 


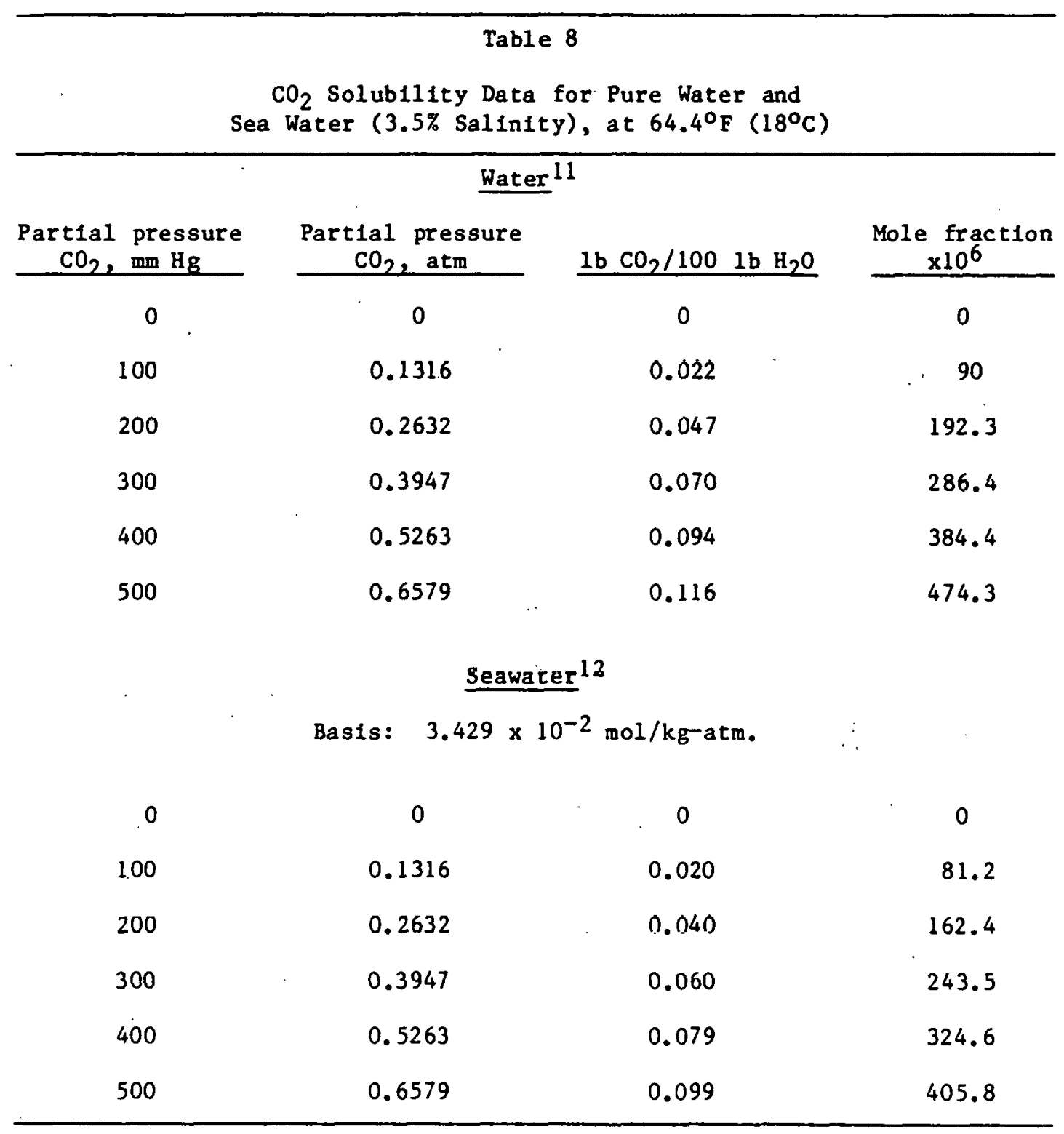


Table 9

Summary of $\mathrm{CO}_{2}$ Absorber Design Data

and Results for $\mathrm{CO}_{2}$ Removal Efficiencies

of 60 and 90 Percent

Seawater Absorption/Disposal

\begin{tabular}{|c|c|c|}
\hline & $\underset{60 \%}{\mathrm{CO}_{2} \text { removal }}$ & $\underset{90 \%}{\text { Lefficiency }}$ \\
\hline$x_{1}$, mf $\mathrm{CO}_{2}$ in outlet seawater & $70 \times 10^{-6}$ & $80 \times 10^{-6}$ \\
\hline $\mathrm{x}_{2}$, mf $\mathrm{CO}_{2}$ in inlet seawater & $0.2 \times 10^{-6}$ & $0.2 \times 10^{-6}$ \\
\hline$y_{1}$, mf $\mathrm{CO}_{2}$ in inlet gas & 0.1340 & 0.1340 \\
\hline$y_{2}$, mf $\mathrm{CO}_{2}$ in outlet gas & 0.0536 & 0.0134 \\
\hline $\mathrm{N}_{\mathrm{OL}}$, number of overall 11 quid-phase transfer units & 3.3 & 16.3 \\
\hline m, slope of equilibriun line & 1620 & 1620 \\
\hline $\mathrm{L}_{\mathrm{m}} / \mathrm{G}_{\mathrm{m}}$, molar ratio of 1 iquid to gas & $1217-1493$ & $1533-1981$ \\
\hline$L / G$, mass ratio of liquid to gas & $754-927$ & $949-1271$ \\
\hline$G$, mass velocity of gas, $1 \mathrm{~b} /(\mathrm{sec})\left(\mathrm{ft}^{2}\right)$ & $0.020-0.018$ & $0.017-0.014$ \\
\hline $\mathrm{H}_{\mathrm{OL}}$, helght of overall liquid-phase transfer unit, feet & 7 & 8 \\
\hline$h$, packing height, feet & 23 & 130 \\
\hline$\Delta \mathrm{P} /$ foot packing, inches water & 0.5 & 0.5 \\
\hline$\Delta P /$ tower, inches water & 15 & 70 \\
\hline Tower diameter, feet & 20 & 20 \\
\hline Overall tower height, feet (approx.) & 42 & 150 \\
\hline No. towers & $84-90$ & $100-107$ \\
\hline
\end{tabular}




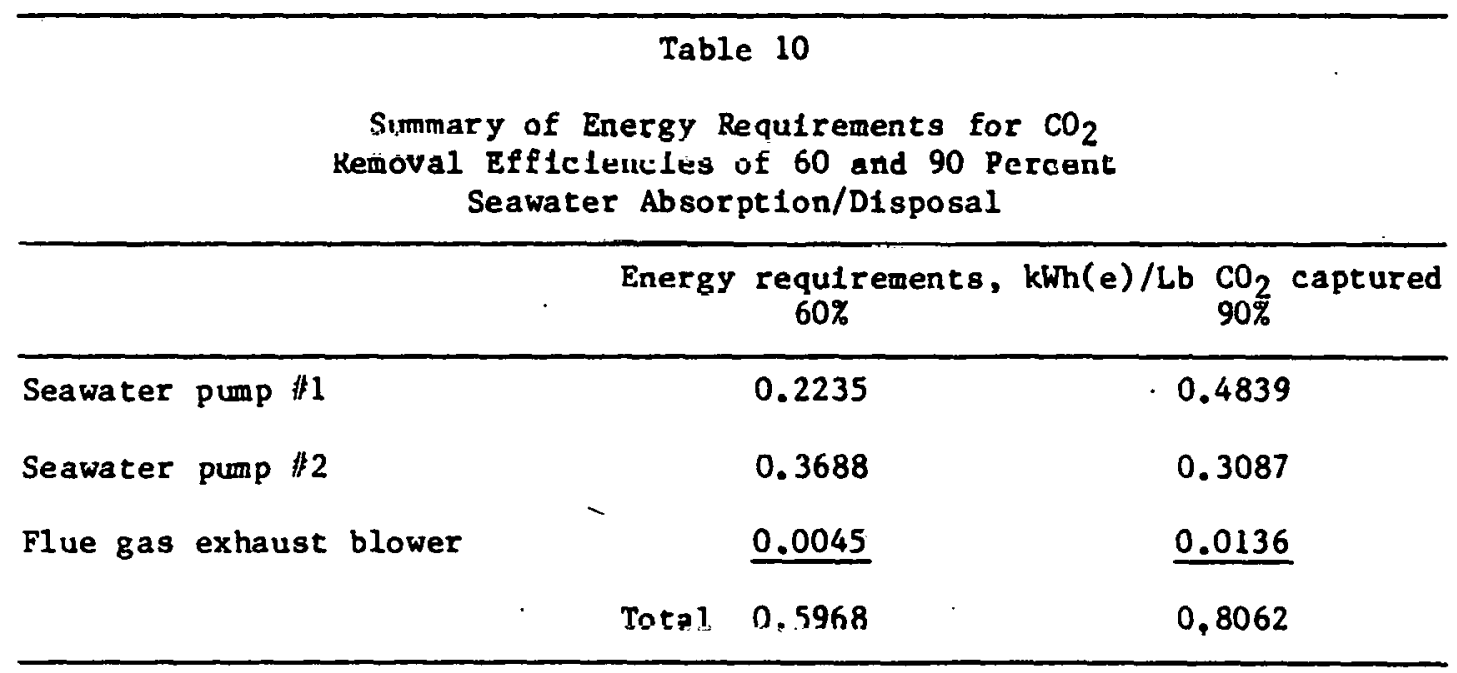


Table 11

Estimated Equipment Requirements and Investment and

Operating Costs for $\mathrm{CO}_{2}$ Removal and Disposal Systems

200-MW(e) Power Plant

Seawater Absorption/Disposal

\begin{tabular}{|c|c|c|c|c|}
\hline & $\begin{array}{l}\text { No. } \\
\text { units }\end{array}$ & Size/capacity & (Millions of dollars) & $\begin{array}{c}\text { Yearly operating }(2) \\
\text { costs } \\
\text { (m1llions of dollars) }\end{array}$ \\
\hline \multicolumn{5}{|l|}{ Case I $(n=0.6)$} \\
\hline Towers & 87 & $20^{\prime} \mathrm{D} \times 42^{\prime} \mathrm{H}$ & 16.9 & - \\
\hline Plpling (principal) & - & 48"I.D.x10 mi & $15.8^{(1)}$ & - \\
\hline Pumps & 174 & $36,000 \mathrm{GPM}$ & 89.3 & 35.3 \\
\hline \multirow[t]{2}{*}{ Blowers } & 1 & 500,000 SCFM & 1.3 & 0.2 \\
\hline & & & 123.3 & 35.5 \\
\hline \multicolumn{5}{|l|}{ Case II $(n=0.9)$} \\
\hline Towers & 104 & $20^{\prime} \mathrm{D} \times 150^{\prime} \mathrm{H}$ & 94.6 & - \\
\hline Piping (principal) & -- & 48 "I.D. $\times 10 \mathrm{mI}$ & $15.8^{(1)}$ & - \\
\hline Pumps & 208 & $36,000 \mathrm{GPM}$ & 113.0 & 70.9 \\
\hline \multirow[t]{2}{*}{ Blowers } & 1 & $500,000 \mathrm{SCFM}$ & 3.4 & 1.3 \\
\hline & & & 226.8 & $72 . ?$ \\
\hline
\end{tabular}

(1) \& $\$ 300$ per ft.

(2) Utflities only - labor, malntenance, etc. not included; 8000 hours of operation per year; electricity at $30 \mathrm{mills} / \mathrm{kWh}$. Refer to discussion under system costs on page 19 of this report.

(3) The fixed capital investment and yearly operating cost (ut1lities and raw materials only) of a lime slurry $\mathrm{SO}_{2}$ scrubbing system (200 MWe plant) are roughly $\$ 20,000,000$ and $\$ 1,700,000$, respectively, assuming $3.3 \%$ sulfur coal (dry basis), an $80 \% \mathrm{SO}_{2}$ removal efficiency, and on-site disposal of spent slurry. 
Table 12

Investment and Operating Costs for MEA Absorption and Deep Ocean Disposal of Flue Gas $\mathrm{CO}_{2}$ From 200-MW(e) Coal-Fired Power Plant

Case I $(n=0.5)$

Fixed capital

investment (1)

(millions of dollars)

A. Tasenils dispnsal

Removal \& recovery

$18(2)$

Compression

3

Piping (14 in. $\times 100 \mathrm{mi}$ )

106

127

B. Liquid disposal

Removal \& recovery

$18(2)$

Liquefaction

4

Piping (10 in. x $200 \mathrm{mi}$ )

$\underline{158}$

180

C. Solid disposal

Removal \& recovery

Sol1dification

20

Barg Ing

$\underline{--}$

38

(1) Ylant investment does not 1nclude cusls uf equipment tor reclaiming degraded MEA.

(2) Estimated from ref. 19, 20, and 21. 


Table 13
Investment and Operating Costs for MEA Absorption
and Deep Ocean Disposal of Flue Gas $\mathrm{CO}_{2}$. From
200-MW(e) Coal-Fired Power Plant

Case II $(n=0.9)$

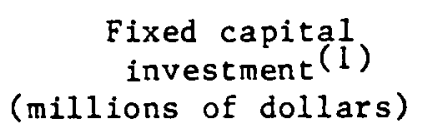

A. Gaseous disposal

Removal \& recovery

$25(2)$

Compression

Plping (18 in. $x 100 \mathrm{mi}$ )

$\underline{132}$

162

B. Liquid disposal

Removal \& recovery

Liquefaction

6

Piping (12 in. x $200 \mathrm{mi}$ )

$\underline{211}$

C. Solid disposal

Removal \& recovery

Solidification

32.

Barging

(1) Plant investment does not include costs of equipment for reclaiming degraded MEA.

(2) Escimated from ret. $19 ; 20$, and 21 . 
Table 14

Cost: 3 of Generating Electricity

Wis th and Without $\mathrm{CO}_{2}$ Control

for Initial Power Plant Capacity

$$
\text { of 200-Mw(e) }
$$

\begin{tabular}{|c|c|c|c|c|c|c|c|c|c|c|}
\hline & $\begin{aligned} \mathrm{sO}_{2} \\
\text { no }\end{aligned}$ & $\begin{array}{l}\text { removal. with } \\
\mathrm{CO}_{2} \text { control }\end{array}$ & Gaseous & $\begin{array}{l}\mathrm{SO}_{2} \text { remo } \\
\text { disposal }\end{array}$ & $\begin{array}{l}\text { oved plus } 50 \% \mathrm{CO}_{2} \\
\text { Liquld disposal }\end{array}$ & $\begin{array}{l}\text { control } \\
\text { Solid disposal }\end{array}$ & Gasewue & $=\underset{\mathrm{SO} \mathrm{O}_{2} \mathrm{ren}}{\mathrm{S1sposal}}$ & $\begin{array}{l}\text { moved plus } 90 \% \mathrm{CO}_{2} \\
\text { LIquid disposal }\end{array}$ & $\begin{array}{l}\text { control } \\
\text { Solid disposal }\end{array}$ \\
\hline Net capac1ty, (1) MW(e) & & 200 & & 161 & 159 & 134 & & B6 & 83 & 37 \\
\hline $\begin{array}{l}\text { Capital Investment MS } \\
\text { (a) Power plaat (2) } \\
\text { (b.) } \mathrm{CO}_{2} \text { control system (3) } \\
\text { Total }\end{array}$ & & $\begin{array}{c}160 \\
\frac{-}{160}\end{array}$ & & $\begin{array}{l}160 \\
\frac{152}{312}\end{array}$ & $\begin{array}{l}160 \\
\frac{216}{376}\end{array}$ & $\begin{array}{r}160 \\
46 \\
206\end{array}$ & & $\begin{array}{l}160 \\
\frac{194}{354}\end{array}$ & $\begin{array}{l}160 \\
\frac{290}{450}\end{array}$ & $\begin{array}{r}160 \\
\frac{68}{228}\end{array}$ \\
\hline $\begin{array}{l}\text { Operating costs, (4) MM\$/year } \\
\text { (a) Coal } \$ 30 / \text { ton } \\
\text { (b) OsM } \\
\text { (c) Barging costs }(5,6) \\
\text { (d) Capital charges e } 15 \% \text { of } \\
\text { Capital Investment } \\
\text { Total }\end{array}$ & & $\begin{array}{r}18.9 \\
4.8 \\
-\overline{24.0} \\
47.7\end{array}$ & & $\begin{array}{r}18.9 \\
5.8 \\
46.8\end{array}$ & $\begin{array}{r}18.9 \\
5.8 \\
56.4\end{array}$ & $\begin{array}{r}18.9 \\
7.2 \\
5.0 \\
30.9\end{array}$ & & $\begin{array}{r}18.9 \\
5.8 \\
53.1\end{array}$ & $\begin{array}{r}18.9 \\
5.8 \\
-- \\
67.5\end{array}$ & $\begin{array}{r}18.9 \\
7.2 \\
5.0 \\
34.2\end{array}$ \\
\hline $\begin{array}{l}\text { Electricity generation costs, } \\
\text { M11ls/kWh (revenue requiremente }\end{array}$ & & 30 & & 56 & 64 & 58 & & 113 & 139 & 221 \\
\hline
\end{tabular}

(1) Electrical energy to drive tie $\mathrm{CO}_{2}$ control system 18 as gumed to be obtalned frow the electrical outpit of the power plant, therefore: $e_{\text {net }}=e_{\text {gross }}(200$ MWe $)-e_{\text {control. }}$

(2) Total capital investment a $\$ 300 / \mathrm{kW}(\mathrm{e})$ Including FGD.

(3) Total capital investment 1.2 times fiked capital Inveetment (Tables 12 and 13).

(4) Based on 8000 hours of operation per year.

(5) Dry 1ce barging costs $\$ 15,300$ per day; costs for traneporting dry lce frow power plant to barge are mot 1neluded.

(6) Barging costs are based an a 100-mlle barging distance (500-meter disposal depth); for a 200-mile distance (3000-meter disposal depth), barging costs are estimated at 9 million dollars per yeer. 


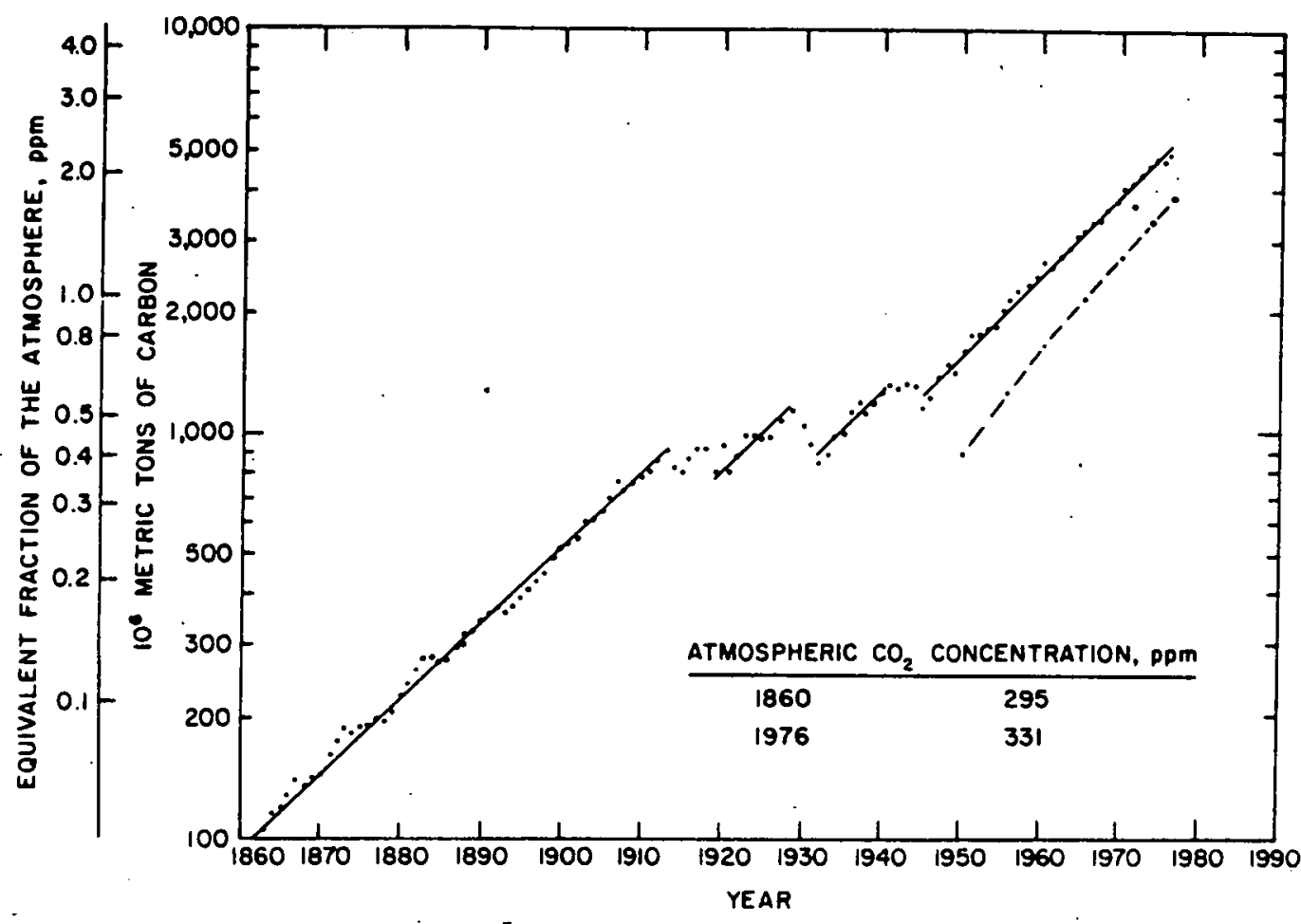

Figure 1. $\mathrm{CO}_{2}$ Production from Fossil Fuels and Cement.

Worldwide less U.S. Sources

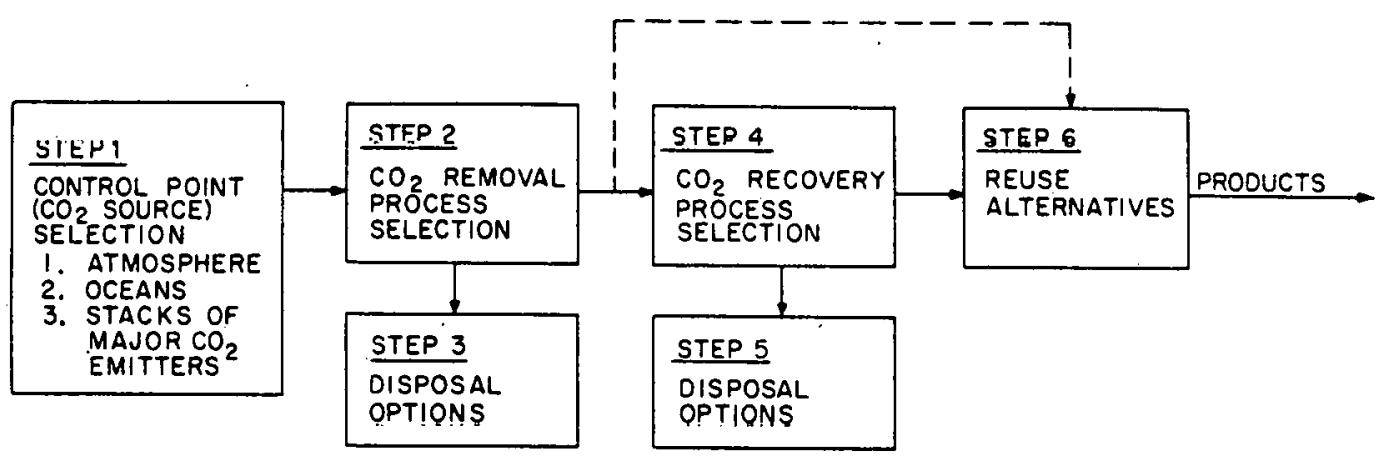

Figure 2. Logic Diagraim fur $\mathrm{CO}_{2}$ Control. 


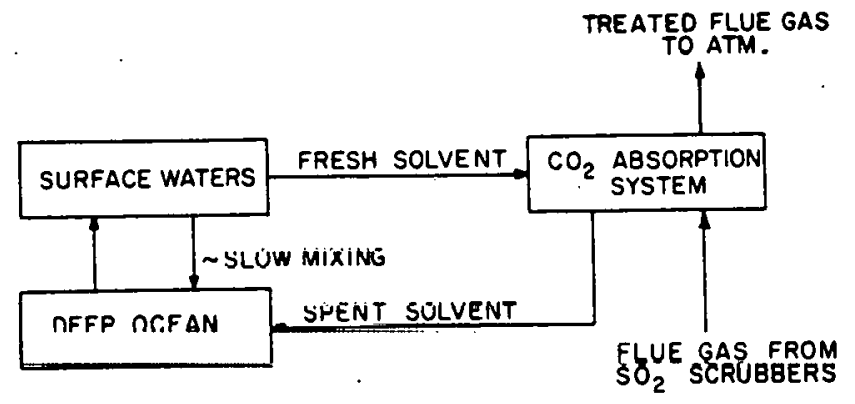

Figure 3. Absorption and Disposal of $\mathrm{CO}_{2}$ Generated by Coa1-Fired Power Plants, Using Seawater.

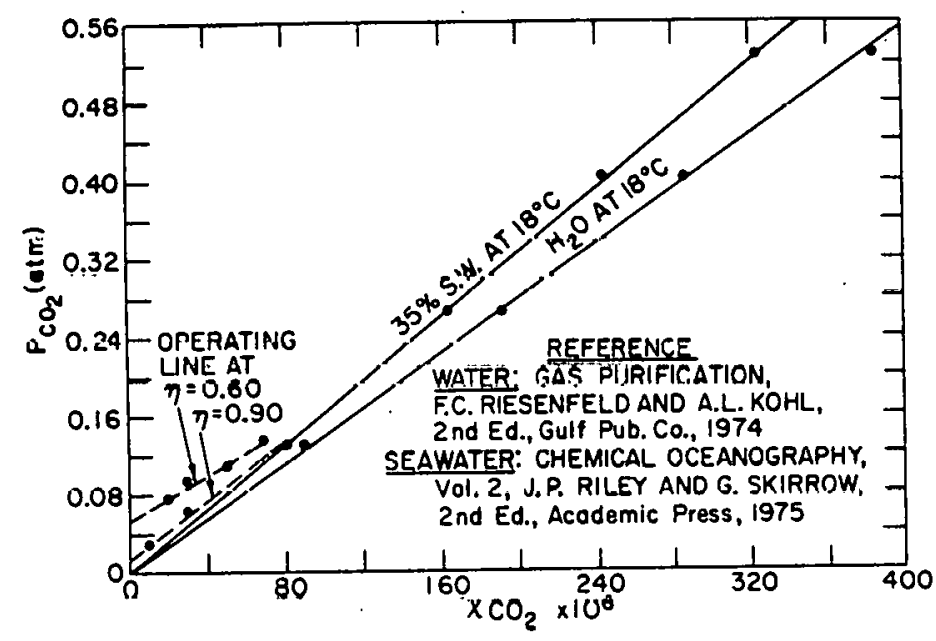

Figure 4. Equilibrium Partial Pressure of $\mathrm{CO}_{2}$ Versus Mole Fraction in Water and in Seawater (3.5\% salinity). 


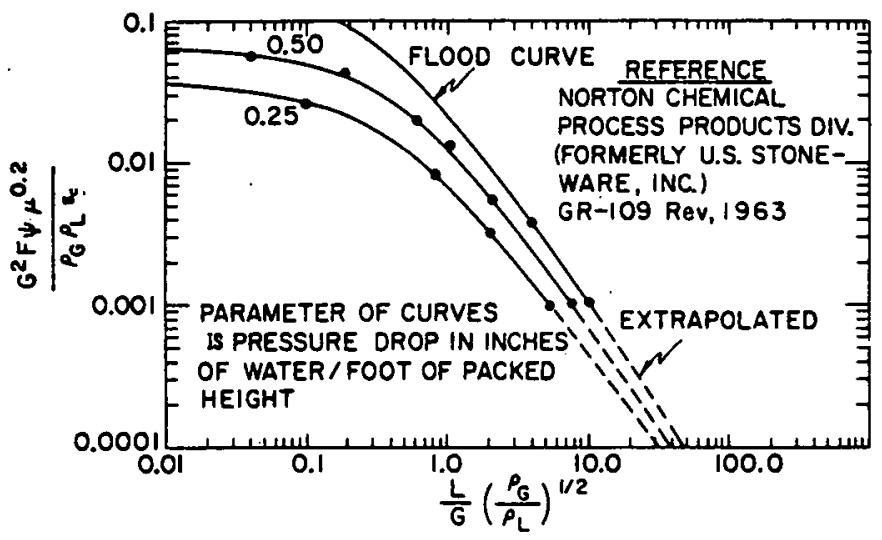

Figure 5. Generalized Pressure Drop Correlation for Sizing Packed Towers.

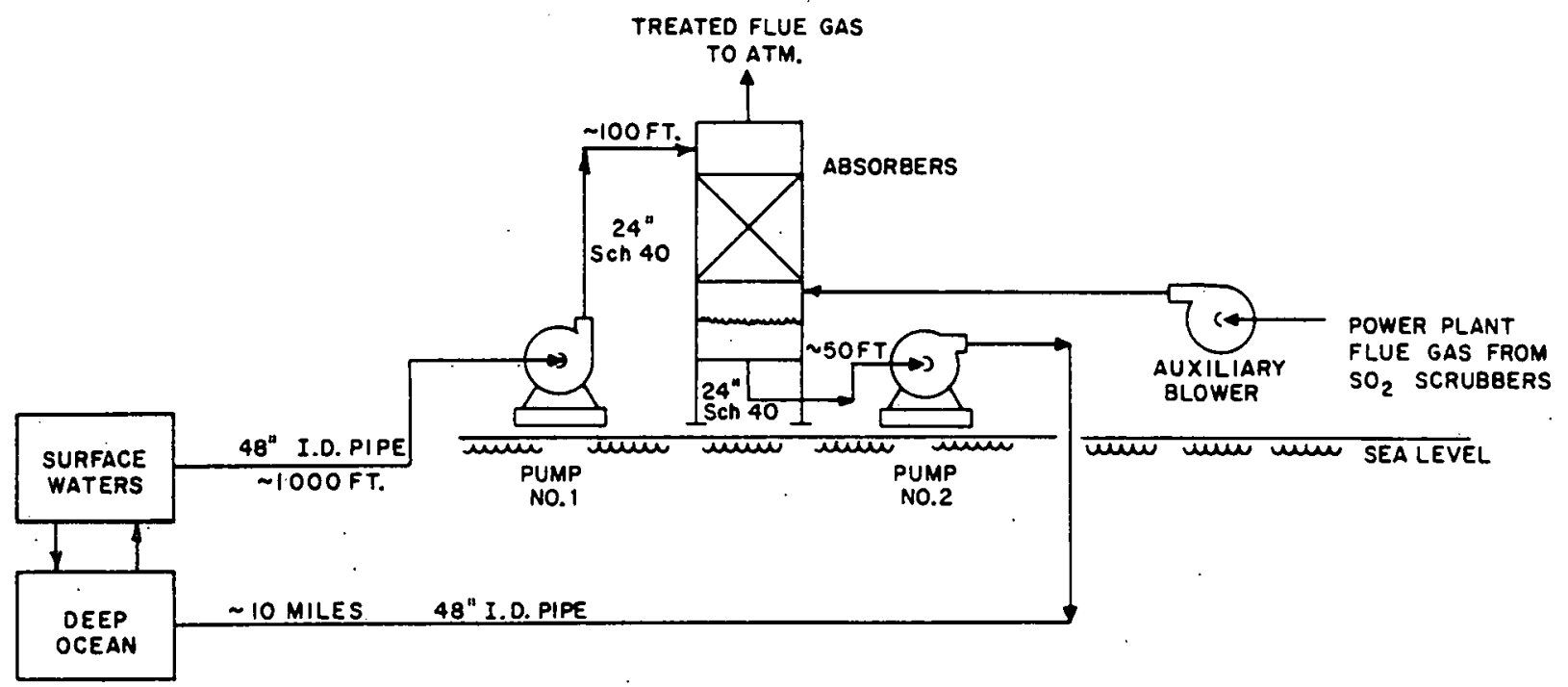

Figure 6. Flowsheet for $\mathrm{CO}_{2}$ Absorption Disposal from Power Plant Flue Gas Using Seawatei. 


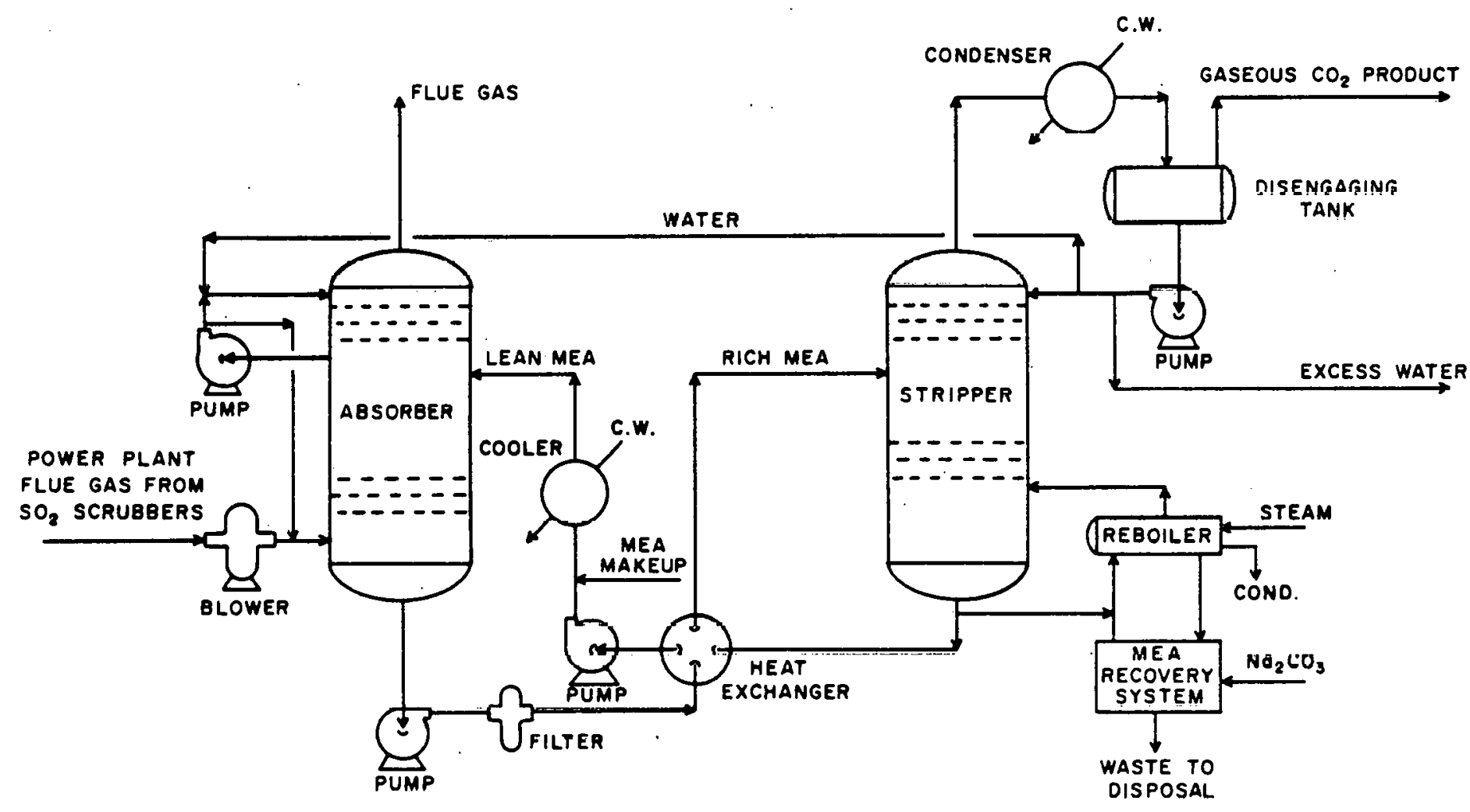

Figure 7. Flowsheet for $\mathrm{CO}_{2}$ Absorption Recovery from Power plant Flue Gas Using MEA. 
Case I $(\eta=0.5)$

A. Gaseous D1sposal

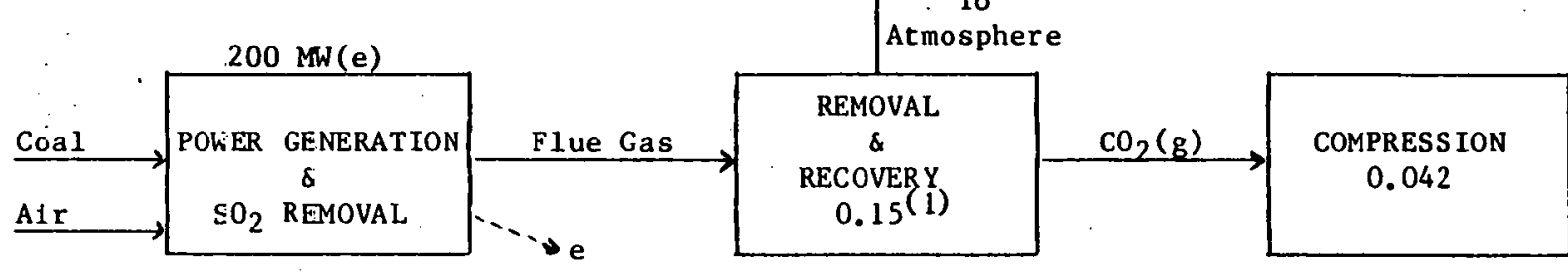

Total Energy for $\mathrm{CO}_{2}$ Removal/Recovery \& Disposal

$=0.192 \mathrm{KWH}(\mathrm{e})$ per pound of $\mathrm{CO}_{2}$ recovered. $\frac{\mathrm{CO}_{2}(\mathrm{~g})}{100 \text { mile } 10 \mathrm{n}}$

Deep Ocean

B. Liquid Disposal
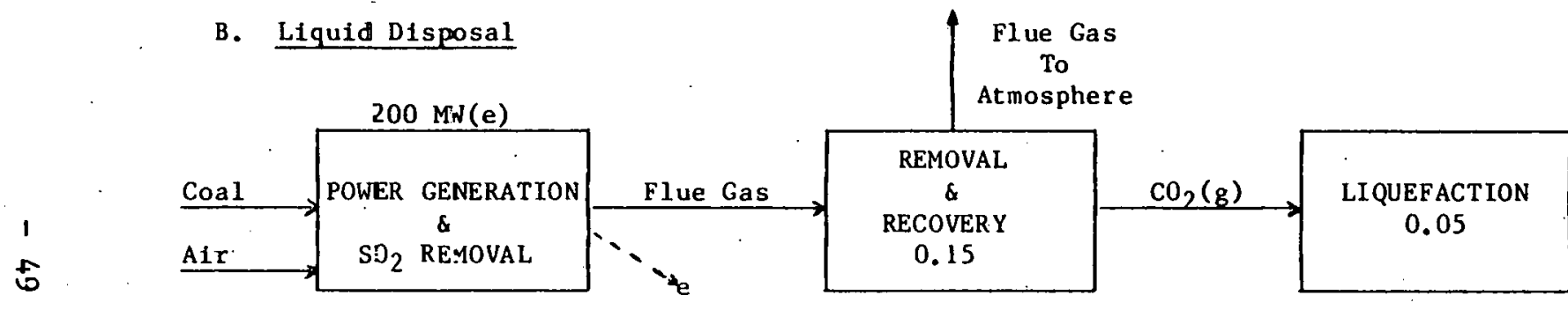

Total Enerzy fo: $\mathrm{CO}_{2}$ Removal/Recovery \& Disposal

$=0.200 \mathrm{KW} . \mathrm{H}(\mathrm{e})$ per pound of $\mathrm{CO}_{2}$ recovered.

(500 meters)

C. Solid Disposal

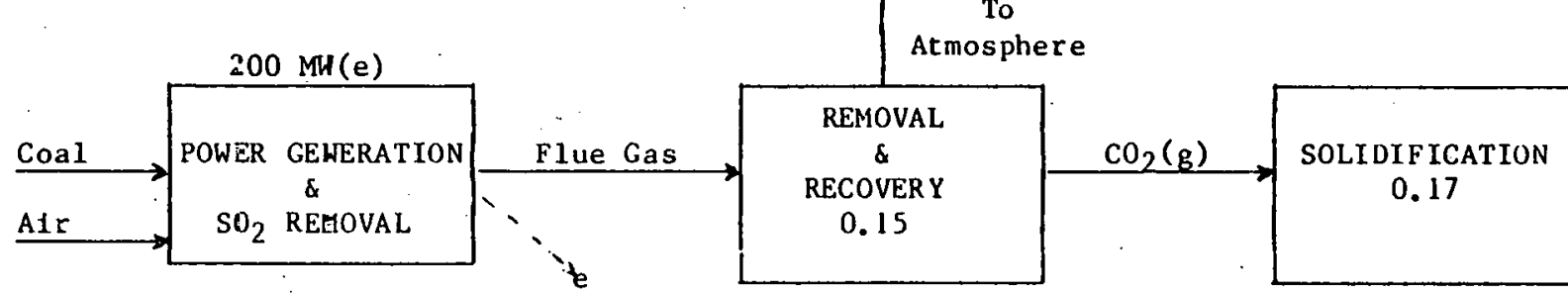

Total Energy for $\mathrm{CO}_{2}$ Removal/Recovery \& Disposal

$=0.325 \mathrm{KWH}(\mathrm{e})$ per pound of $\mathrm{CO}_{2}$ recovered.

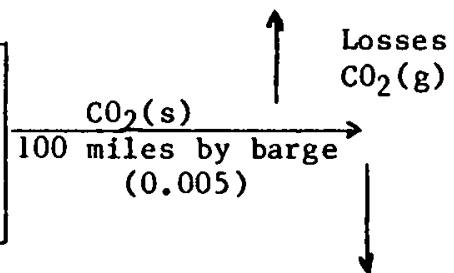

Note:

(1) Equivalert energy requirement in KWH(e) per pound of $\mathrm{CO}_{2}$ recovered.

Figure 8. Energy Requirements for MEA Absorption and Deep Ocean Disposal of Flue Gas $\mathrm{CO}_{2}$ from $200 \mathrm{MW}(\mathrm{e})$ Coal Fired Power Plant. 


\section{A. Gaseous Disposal}
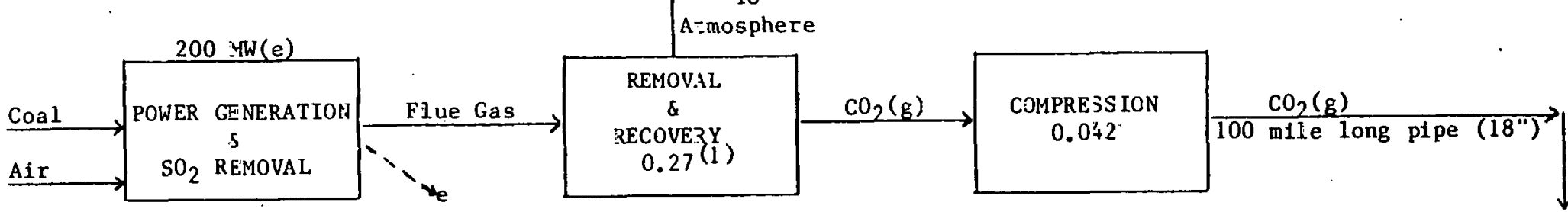

$$
\left\{\begin{array}{c}
\text { Flue Gas } \\
\text { To } \\
\text { A-mosphere }
\end{array}\right.
$$

Total Energy for $\mathrm{CO}_{2}$ Remov: $31 /$ Recovery \& Disposal Deep Ocean

$=0.312 \mathrm{KWH}(\mathrm{e})$ per pound of $\mathrm{CO}_{2}$ recovered. (500 meters)

\section{B. Liquid Disposal}

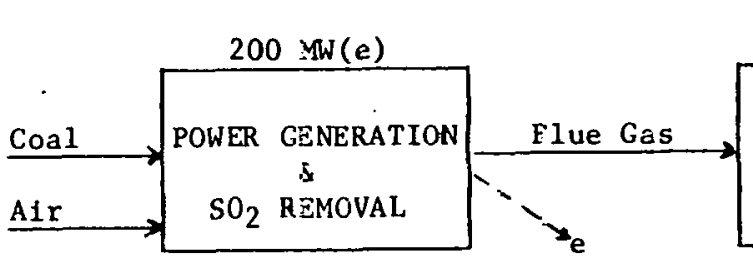

Flue Gas

$$
\begin{gathered}
\text { To } \\
\text { Atmosphere }
\end{gathered}
$$

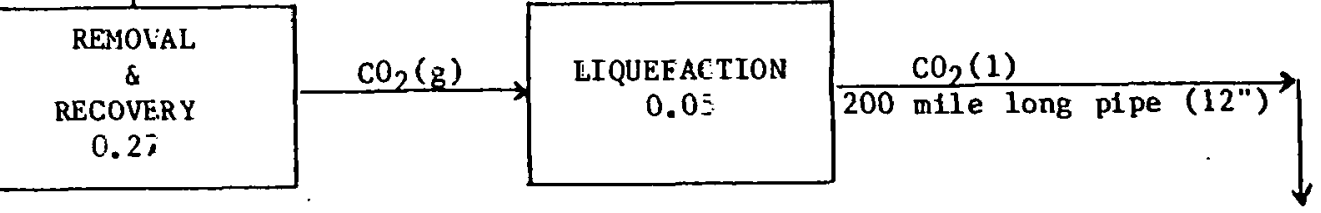

Total Energy for $\mathrm{CO}_{2}$ Remova:/Recovery \& Disposal Deep Ocean $=0.320 \mathrm{KWH}(\mathrm{e})$ per pound of $\mathrm{CO}_{2}$ recovered. (3000 meters)

\section{Sol1d Disposal}
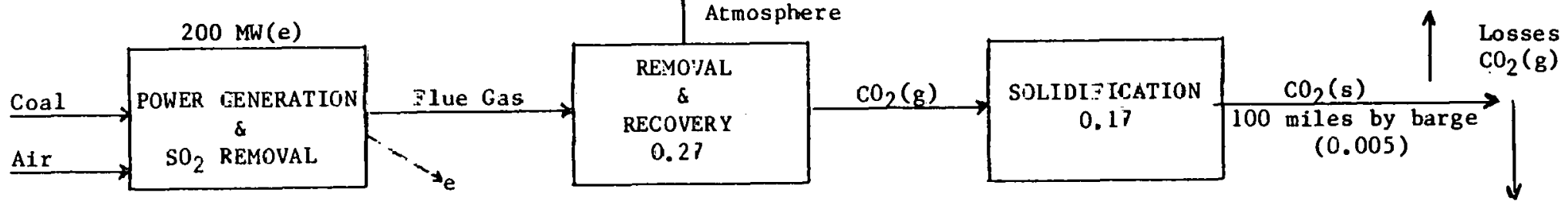

Total Energy for $\mathrm{CO}_{2}$ Removal/Recovery \& Disposal

$=0.445 \mathrm{KWH}(\mathrm{e})$ per pound of $\mathrm{CO}_{2}$ recovered.

Note:

(1) Equivalent energy requirement in $\mathrm{KWH}(e)$ per pound of $\mathrm{CO}_{2}$ recovered.

Figure 9. Energy Requirements for MEA Absorption and Deep Ocean Disposal of Flue Gas $\mathrm{CO}_{2}$ from $200 \mathrm{MW}(\mathrm{e})$ Coal Fired

Power Plant. 


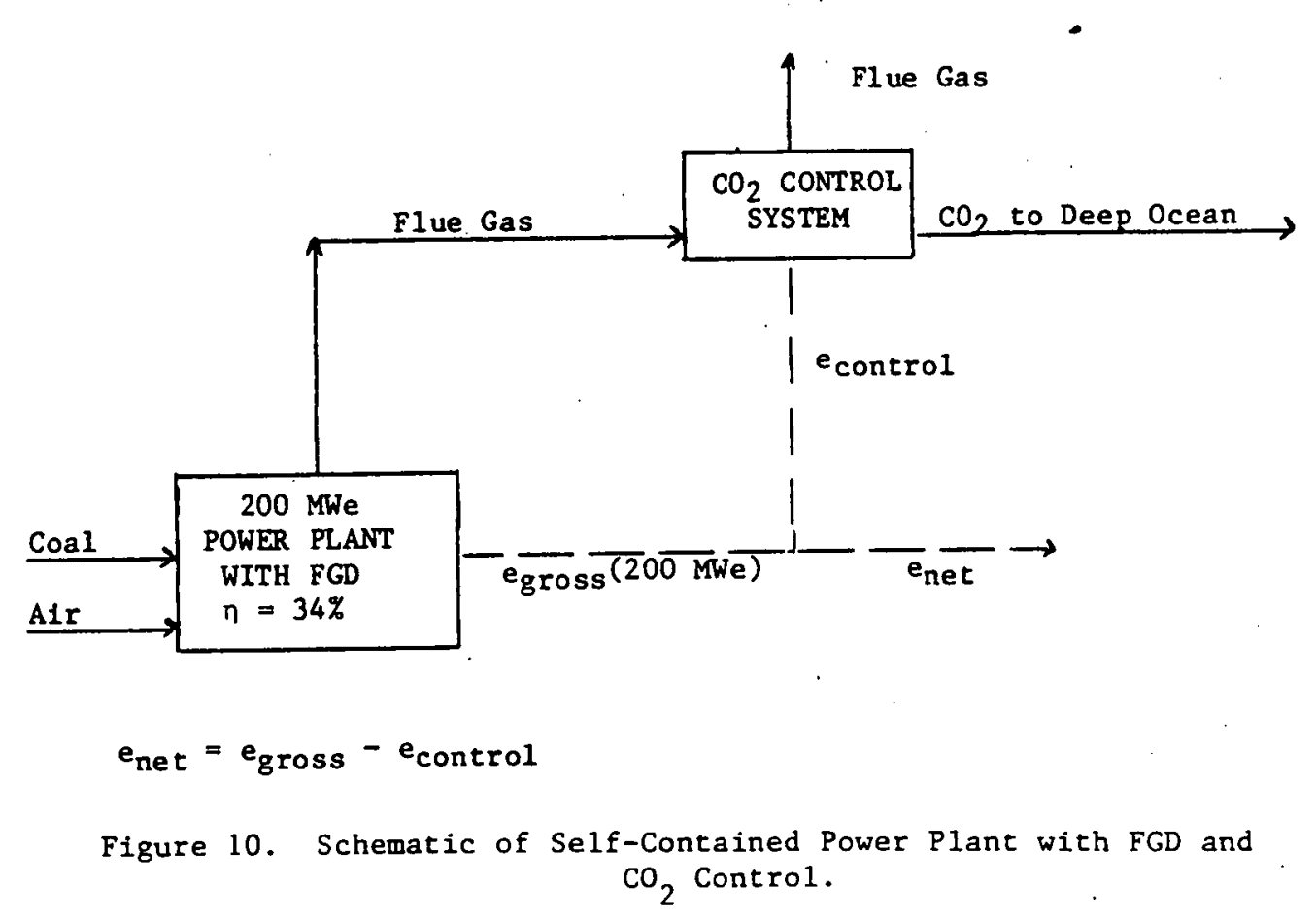




\section{Distribution}

U. S. Department of Energy

Environmental Control Technology
W. E. Mott
M. Gottlieb
F. E. Witmer

Brookhaven National Laboratory
W. E. Winsche
B. Muliuwitz
D. Gurinsky
M. Stelnberg
A. S, Albanese
V. Dang 